\title{
The Effect of Corruption on Investment Growth: Evidence from Firms in Latin America, Sub-Saharan Africa and Transition Countries.
}

\author{
Elizabeth Asiedu, asiedu@ku.edu \\ Department of Economics, University of Kansas \\ James Freeman, jfreeman@wheatoncollege.edu \\ Department of Economics, Wheaton College
}

Please address all correspondence to:

Elizabeth Asiedu

Department of Economics

University of Kansas, Lawrence, KS 66045

Phone: (785) 864-2843; E-mail: asiedu@ku.edu 


\title{
The Effect of Corruption on Investment Growth: Evidence from Firms in
}

\section{Latin America, Sub-Saharan Africa and Transition Countries.}

\author{
Elizabeth Asiedu, asiedu@ku.edu \\ Department of Economics, University of Kansas \\ Lawrence, Kansas \\ James Freeman, jfreeman@wheatoncollege.edu \\ Department of Economics, Wheaton College \\ Norton, Massachusetts
}

\begin{abstract}
Many of the empirical studies that analyze the impact of corruption on investment have three common features: they employ aggregate (country-level) data on investment, corruption is measured at the country-level, and data for countries from several regions are pooled together. This paper uses firm-level data on investment and measures corruption at the firm and countrylevel, and allows the effect of corruption to vary by region. Our dependent variable is firms' investment growth and we employ six measures of corruption from four different sources: two firm-level measures and four country-level measures. We find that the effect of corruption on investments varies significantly across regions: corruption has a negative and significant effect on investment growth for firms in Transition countries but has no significant impact for firms in Latin America and Sub-Saharan Africa. Furthermore, among the variables included in the regressions (firm size, firm ownership, trade orientation, industry, GDP growth, inflation and openness to trade) corruption is the most important determinant of investment growth for Transition countries.
\end{abstract}

JEL classification: G31, O16

Keywords: Bribery, Corruption, Firm, Investment, Latin America and Caribbean, Sub-Saharan Africa, Transition Countries. 


\section{Introduction}

There is a vast empirical literature on the effect of corruption on investment. However, most of the studies use country-level (aggregate) data on investments for their analysis — our literature review revealed only three papers that have analyzed the effect of corruption on firmlevel investments. The paucity of research on how corruption affects firm behavior is noted in Svensson (2003, pp. 209) who writes that "despite more than two decades of research, however, economic studies on corruption at the firm level are rather limited." Wei (2001, pp. 11) conducts an extensive review of the corruption-investment literature and concludes that "firm-level studies are generally rare, for the obvious reason that firm-level data are more difficult to assemble." Analyzing how corruption affects firm-level investment is important because reports from several surveys suggest that corruption affects firm performance. For example, about $74 \%$ of the firms that participated in the World Business Environment Survey (WBES) conducted by the World Bank (described in detail in Section 5) reported that corruption was an obstacle to the operation and growth of their business.

This paper contributes to the investment-corruption literature by examining the impact of corruption on firm-level investment growth. ${ }^{1}$ Another contribution of the paper is that we run

\footnotetext{
${ }^{1}$ Several studies have examined the effect of corruption on foreign direct investment (FDI). In contrast, we focus on all firms, both domestic and foreign, operating in a country. There are three reasons. First, our dataset includes few foreign-owned firms (just about 10 percent of the total sample). Second, we tested whether the effect of corruption on investment is significantly different between domestic and foreign owned firms, and our data did not support this hypothesis. The third reason is that countries in need of investments may be more interested in promoting private investments - both domestic and foreign. Indeed, promoting private domestic investment is particularly important for countries that have been unsuccessful in attracting FDI, in particular countries in Sub-Saharan Africa (Asiedu, 2004).
} 
separate regressions for firms in three regions, Transition countries, Sub-Saharan Africa (SSA) and Latin America and the Caribbean (LAC), and we analyze whether the effect of corruption on investment growth differs systematically across the three regions. Our approach contrasts with most studies that pool data from several regions into one sample. Indeed, if the underlying relationship between corruption and investment is different for the various regions (as we find in this paper), then results based on a pooled sample may significantly misrepresent the true relationship between corruption and investment.

Our analysis covers 2,752 firms in 53 developing countries with a breakdown as follows: 1,278 firms in 18 Transition countries, 910 firms in 19 countries in LAC and 564 firms in 16 countries in SSA. We find that the effect of corruption on firm investment growth varies significantly by region: corruption has a negative effect on firm investments for Transition countries but has no significant impact for LAC and SSA. Furthermore, among the variables included in the regressions (firm size, firm ownership, trade orientation, industry, GDP growth, inflation and openness to trade) corruption is the most important determinant of investment growth for Transition countries.

The rest of the paper is organized follows. Section 2 provides a brief discussion of the theoretical relationship between investment and corruption, section 3 discusses the advantages and drawbacks of the various types of corruption measures, section 4 presents a brief literature review, section 5 describes the data and the variables used in the regressions, section 6 presents the empirical results, and section 7 concludes. 


\section{Investment and Corruption}

The theoretical literature on corruption suggests that the impact of corruption on firmlevel investment is unclear. On the one hand, corruption raises operational cost, creates uncertainty and thereby deters investment (cf., Shleifer and Vishny, 1993; Wei, 1997 and Campo et al., 1999). Furthermore, models of firm investment under uncertainty show that if capital is partially irreversible, then greater uncertainty about future returns on investment increases the option of waiting to undertake an irreversible investment (Pindyck and Dixit, 1994). ${ }^{2}$ However, the negative effect of corruption can be neutralized or offset in situations where corruption creates opportunities for private illicit gains to firms — such as paying "cash for contracts." Indeed, in many developing countries, firms sometimes pay bribes to win a lucrative government contract, to have access to raw materials at state subsidized prices, to obtain credit at below market interest rates, to acquire scarce foreign exchange or collude with tax collectors to reduce tax payments. ${ }^{3}$ For example, in August 2006, the Department of Institutional Integrity, a special unit of the World Bank in charge of investigating fraud in World Bank projects announced that it had found evidence that an Indonesian firm had made "facilitation and gratis payments exceeding $\$ 300,000$ to officials of Ministry of Public Works," in connection with a \$6 million transportation project funded by the World Bank. ${ }^{4}$ The issue of cash for contract is well

\footnotetext{
${ }^{2}$ Other models of firm investment under uncertainty show that greater uncertainty can have a positive effect on firm investment (Abel, 1983; Abel and Eberly, 1996) or an ambiguous effect on firm investment (Abel et al., 1996).

${ }^{3}$ See Courtney (2002) for examples of bribery in the privatization of state of owned enterprises in developing countries and Hall (1999) for examples of incidents involving bribery in the allocation of defense contracts.

${ }^{4}$ For more on this issue, see

http://web.worldbank.org/WBSITE/EXTERNAL/COUNTRIES/EASTASIAPACIFICEXT/INDONESIAEXTN/0,c ontentMDK:20983649 pagePK:141137 piPK:141127 theSitePK:226309,00.html
} 
articulated by Rose-Ackerman (1996, p. 1) who notes that "when the government is a buyer or a contractor, ... a corrupt firm may pay to be included in the list of qualified bidders, to have officials structure the bidding specifications so that it is the only qualified supplier, or to be selected as the winning contractor. And once selected, it may pay for the opportunity to charge inflated prices or to skimp on quality." Thus, all else equal, firms that benefit from corruption may expand their activities by increasing investments (Hellman et al., 2002). ${ }^{5}$ This suggests that the overall theoretical impact of corruption on firm-level investment is unclear: it can be negative, positive or neutral, depending on which of the two opposing effects dominate. Thus, the effect of corruption on firm-level investment is an empirical issue.

\section{Measures of Corruption}

The corruption measures that are readily available and have been employed in previous empirical studies can be broadly classified into three categories. For convenience and exposition, we refer to the three categories as internal, external and hybrid. Internal measures of corruption are based on the experiences/perceptions of firms that operate within the country. The typical procedure is to survey the firms in a country about their perceptions/experiences of corrupt practices in the country. The survey may include questions about the frequency and size of bribes paid to government officials. ${ }^{6}$ One advantage of using internal measures in determining the effect of corruption on investments is that it partly reflects firms' perception of investments risk, which happens to be one of the most relevant factors that shape firms' operational and

\footnotetext{
${ }^{5}$ Hellman et al. (2002) conclude that in highly-corrupt Transition countries, firms that engage in corrupt practices tend to grow substantially faster than other firms.

${ }^{6}$ Examples of internal measures of corruption are the information on bribes collected as part of the World Business Economic Survey and World Development Report Survey, conducted by the World Bank.
} 
investments decisions. However, internal measures have several limitations. First, the firms that provide the corruption ratings operate in different countries and therefore face different policy environments and economic settings. As a consequence, their point of reference is likely to be different and thus the data may not be easily comparable across countries. For example, firms that operate in countries where corruption is prevalent may be accustomed to corruption and therefore have less stringent standards for judging corrupt practices (Cameron et al., 2005). ${ }^{7}$

The second limitation of internal measures of corruption is that the data are likely to be influenced by firm-specific attributes, such as firm size. For example, corruption ratings provided by large firms may be different from the ratings provided by smaller firms. This suggests that countries with the same level of corruption but different composition of firms with regards to size (large versus small) may have different internal corruption ratings. The third disadvantage is that corruption may be under-reported, as respondents may be reticent about providing answers to sensitive questions such as corruption (Azfar and Murrell, 2005). It is also possible that government censorship may preclude surveys from asking questions on corruption. For example, in the WBES, questions on corruption were not included in the questionnaire for firms in China due to government policies. Clearly, these measurement problems are likely to bias the estimation results.

The second type of corruption measure, external, is based on the assessment of risk analysts who typically reside outside a country. These corruption data are generally provided by private risk rating agencies and are targeted toward foreign investors. ${ }^{8}$ One advantage of external

\footnotetext{
${ }^{7}$ Cameron et al. (2005) find that residents in India exhibit a higher tolerance towards corruption than residents in Australia.

${ }^{8}$ Examples of external measures of corruption are the corruption indices published by Political Risk Services and Economic Intelligent Unit.
} 
measures is that unlike internal measures, countries are rated by the same set of entities (i.e., risk analysts) and therefore the data are generally consistent and less prone to measurement errors. However, external measures also have several limitations. First, the data tend to have limited coverage and are generally not available for small or poor countries, or for countries that receive little foreign investment. Thus, using external corruption measures will automatically exclude several developing countries from the empirical analysis, in particular the countries that are in most need of investments.

Another disadvantage of external measures is that the evaluations of the (foreign) risk analysts are generally not based on personal experience, but often inferred from media reports. As a result, the levels of corruption reported by these "experts" may not accurately reflect the levels of corruption that prevail in a country. Indeed, several studies have found that risk assessments by private rating agencies tend to be biased against poor countries or smaller countries (Ferri, 2004). ${ }^{9}$ Furthermore, the bias is particularly large for countries with an "image" problem, in particular countries in SSA. For example, about 56 percent of the firms that participated in a survey conducted by the United Nations Conference on Trade and Development (UNCTAD) reported that the actual business environment in SSA was better than the continent's image would suggest (WIR, 2000). This view is also consistent with the empirical results of Haque et al. (2000) who find that commercial risk-rating agencies often rate African countries as riskier than warranted by the fundamentals. This caveat of external corruption measures is particularly relevant to our work because our analysis includes several African countries. Finally, external measures of corruption are more relevant at the initial stage of a firm's

\footnotetext{
${ }^{9}$ Ferri (2004) also concludes that commercial risk rating agencies under-invest in information gathering in poor and small countries.
} 
investment decision process when it is deciding whether or not to invest in a country. Once a firm locates in a country, the subsequent operational decisions, such as how much to increase investments, will be shaped by the firm's experience from operating in that environment. ${ }^{10}$

The third corruption measure, the hybrid, combines corruption data from different sources into a composite index. ${ }^{11}$ Note that by combining all types of corruption data (including internal and external measures of corruption), hybrid measures by their nature mitigate the problems associated with the other two measures of corruption. One disadvantage, however, is that since the data are a composite measure, they do not differentiate among various forms of corruption, such as nepotism, embezzlement of public funds or bribery. This could be problematic if different types of corruption have different effects on investment.

Bearing in mind the caveats of the available corruption measure, we employ corruption measures from all three categories for our empirical analysis. Specifically, we use six measures of corruption from four different sources - three internal measures, one external measure and two hybrid measures. Our internal measures are derived from the WBES and they reflect the size of bribe payments by firms to public officials. Our external measure is the International Country Risk Guide corruption index, which captures corruption within the political system, including the "actual or potential corruption in the form of excessive patronage, nepotism, job reservations,

\footnotetext{
${ }^{10}$ The point is that external measures of corruption are more relevant for firms who have no experience or first hand knowledge about the countries in which they wish to invest. Thus, these measures are not helpful when evaluating the effect of corruption on investment decisions by firms that are already operating in a country.

${ }^{11}$ The most widely available hybrid measures of corruption are the Corruption Perception Index (CPI) complied by Transparency International and the Corruption Index, KKM, compiled by Kaufman, Kraay and Mastruzzi (2005). For example, the $2005 \mathrm{KKM}$ corruption measure were based on corruption data from 37 separate sources and 31 different organizations, and the 2005 CPI were based on data from 17 sources and 13 independent institutions.
} 
'favor-for-favors', secret party funding, and suspiciously close ties between politics and business." Our hybrid measures are the Corruption Perception Index published by Transparency International and the Corruption Index compiled by Kaufman, Kraay and Mastruzzi (2005). Using measures of corruption from several sources and from all the three categories of corruption serves as a robustness check and also increases the credibility of our results.

\section{Brief Literature Review}

For discussion purposes, we will categorize the empirical literature on corruption and

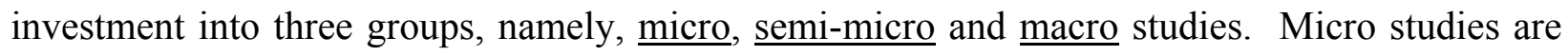
based on firm-level data on investment and firm-level data on corruption. Firm-level data on corruption are obtained from surveys of firms operating within a country, and therefore fall under the category of internal measures of corruption. These measures are idiosyncratic to a firm and they reflect a specific firm's perception of the level of corruption prevailing in the country in which the firm operates. An advantage of a micro-analysis is that it links a firm's perception of corruption to the firm's investment decision. This is important because investment decisions are to a large extent shaped by investor perception and not by "actual" events. However this approach has at least two disadvantages. First, the data for the dependent variable, investment, and the data for corruption are both derived from the same source, (i.e., the same firm) - this raises a potential endogeneity problem. ${ }^{12}$ The second disadvantage is that firm-level measures of corruption fall under the category of internal measures, and therefore the analyses suffer from

\footnotetext{
${ }^{12}$ For example, the estimated effect of corruption will be biased if firms with lower investment growth rates are more likely to report frequent incidences of corruption or if responses to the corruption questions are correlated with unobserved firm characteristics. One way researchers have attempted to mitigate the biases due to endogeneity and measurement errors is to use country level measures of corruptions.
} 
the caveats of internal measures of corruption described above. Our literature review revealed only two micro-studies, Batra et al. (2003) and Gaviria (2002). Both studies use corruption and investment data from the WBES, which is also our primary source of data. Batra et al. (2003) pool data for 3,100 firms in 81 developing and developed countries and find that corruption has a negative and significant impact on investment growth. Gaviria (2002), on the other hand, restricts his analysis to countries in Latin America and the Caribbean. In contrast to Batra et al. (2003), he finds no significant relationship between corruption and firm level investment growth. His analysis covers 2,612 firms in 29 countries.

The second strand of the literature, semi-micro studies, employ firm-level data on investment and country-level data on corruption. Country-level measures of corruption capture the pervasiveness of corruption within a country. An advantage of using country-level measures of corruption is that it mitigates some of the measurement errors and biases associated with firmlevel measures. ${ }^{13}$ However, by using such data, one is implicitly assuming that all firms within a country face the same levels of corruption. With regards to the literature, we found only one semi-micro study, Smarzynska and Wei (2000). The authors analyze how corruption measured at the country level affects a firm's investment decisions. They employ two measures of corruption — data from the World Bank's World Development Report survey, which is an internal measure, and the Corruption Perception Index, compiled by Transparency International, which is a hybrid measure. Their analysis focuses on foreign owned firms in Transition countries and they find that corruption has an adverse effect on investment.

The vast majority of the papers fall under the third category, macro studies, where the analyses employ country-level data on investment and country-level data on corruption (e.g.,

\footnotetext{
${ }^{13}$ For example, using the average of the corruption ratings provided by individual firms reduces measurement error.
} 
Mauro, 1995; Wei, 2000; Rock and Bonnet, 2004; and Pellegrini and Gerlagh, 2004). ${ }^{14}$ Thus, macro-level studies generally examine the extent to which cross-country variations in aggregate investments can be explained by differences in cross-country corruption. The general finding is that corruption deters aggregate investments.

This paper examines how corruption measured at the firm and the country level affect firms' investment growth. Thus, we carry out a micro and a semi-micro analysis. There are two main reasons for taking a micro approach. As pointed out earlier, most of the studies on the investment-corruption relationship are macro-level studies — very few studies employ firm-level investment data. The second reason is that there are several advantages to using firm-level data on investment. One advantage of using firm level investment data is it permits one to analyze how corruption affects the behavior of the agents that make the investment decisions - i.e., the firm. Such an analysis cannot be carried out using country-level data because using aggregate investment data to explain firm investment behavior is valid only if the relationship between corruption and investment is homogenous across all firms. ${ }^{15}$ Another advantage of using firmlevel data on investment is that it allows one to identify firm characteristics that affect investment decisions. Such an analysis has important policy implications. For example, our analysis suggests that investment growth is higher for firms in the service sector than for firms in other sectors. Thus, a country that seeks investments may want to pursue policies that will attract more service sector firms. A third advantage of using firm level data on investment is that it mitigates some of the econometric problems associated with country-level analysis. For example,

\footnotetext{
${ }^{14}$ See Rock and Bonnet (2004) for a survey of the literature.

15 Thus, macro-level analyses exhibit an aggregation bias. See Garrett (2003) for a detailed discussion of aggregation bias.
} 
most of the macro-studies use GDP growth rate as a determinant of investment. This is problematic because causality may run from investment to growth, giving rise to an endogeneity bias. Note that the potential endogeneity problem is less of a concern when using firm-level data because the investment of an individual firm is less likely to have a significant effect on GDP growth.

This paper extends the existing literature in several ways. First, by utilizing measures of corruption from different sources and from different categories, we provide a comprehensive analysis of the effect of corruption on investment growth. Second, unlike previous studies, we run regressions for the pooled sample, as well as for countries in LAC, SSA and transition countries. Indeed, to the best of our knowledge, this is the first study that analyzes the effect of corruption on firm level investment in SSA. ${ }^{16}$ Such an analysis is important because SSA is perceived to be the most corrupt region and is also the region in most need of investment. Furthermore, there is a widespread notion among policymakers in SSA that conclusions based on studies of non-SSA countries may have little policy relevance to SSA because countries in this region are so different. Therefore, findings from studies that are based solely on SSA will have more credibility with policymakers in the region.

\section{The Data and Variables}

\footnotetext{
${ }^{16}$ A few studies have examined the effect of corruption on firm performance in SSA. Fisman and Svensson (2000) analyze the impact of bribery vis-à-vis taxes on sales growth for firms in Uganda and conclude that bribery is negatively correlated with sales growth and that bribery is more damaging than taxation. McArthur and Teal (2002) employ data for 27 African countries and find that corruption has a significant and negative effect on output per worker.
} 
Our main source of data is the World Business Environment Survey (WBES) conducted by the World Bank in 1999/2000. The purpose of the survey was to identify the factors that constrain business activities in various countries. ${ }^{17}$ The survey covered 10,032 firms in 81 countries and at least 100 firms were surveyed in each country. Within each country, at least 15 percent of the firms had foreign ownership, at least 15 percent were small (fewer than 50 employees) and at least 15 percent were large (more than 500 employees). The countries included in our analysis were determined by the availability of data. Specifically, data on investment and/or corruption as well as data for some of the firm attributes included in the regressions were not available for several of the firms in East Asia, South East Asia and the Middle East and North Africa. ${ }^{18}$ As a result, we restricted our analysis to LAC, SSA and Transition countries.

\section{Dependent Variable}

The dependent variable is the percentage growth in a firm's investment over the period 1996-1998 (i.e., three years prior to the survey). Using data on the amount of investments would

\footnotetext{
${ }^{17}$ The WBES data has been used in several studies, including Beck et al. (2005), Jones et al, (2003) and Batra et al. (2003). For a detailed description of the survey, see Batra et al. (2003). The WBES data are available at http://info.worldbank.org/governance/wbes/.

${ }^{18}$ For example, firms in China did not respond to the question on corruption, while many of the firms in Thailand did not provide information on the dependent variable, investment growth. Also, data on firm investment growth was available only for a few countries in the Middle East and North Africa.
} 
have been preferable, however, the respondents were asked to indicate only the growth in investments and not the actual amounts of investments. ${ }^{19}$

\section{Measures of Corruption}

\section{Firm-Level Measures of Corruption}

We use two firm-level measures of corruption based on firms' response to Question A:

Question A: On the average, what percent of revenues do firms like yours typically pay per annum in unofficial payments to public officials?

(1) $0 \%$

(2) $\quad 1-1.99 \%$

(3) $2-9.99 \%$

(4) $\quad 10-12 \%$

(5) $\quad 13-25 \%$

(6) Over $25 \%$

We define the variable, Bribe_Index such that it corresponds to the six responses. ${ }^{20}$ Thus, Bribe_Index takes on value 1 to 6 where a higher number implies more corruption. The second measure, Bribe_Dummy, is a binary variable which takes on value 1 if a firm reported that at least $2 \%$ of its revenue was paid to government officials as bribes and zero otherwise. Thus, Bribe_Dummy is equal to 1 if firms' response is " 3 ", " 4 ", "5" or " 6 "; and zero otherwise.

19 Previous studies that have employed data from the WBES to analyze the effect of corruption on investment have also used firm level investment growth as the dependent variable (e.g., Batra et al., 2003).

${ }^{20}$ The original ordering of the answers is the reverse of the one shown in Question A. We have re-ordered the answers to facilitate the interpretation of the results. 


\section{Country-Level Measures of Corruption}

We employ four country-level measures of corruption: one internal, one external and two hybrid measures. The internal measure, Bribe_Percent is derived from firms' response to Question A and it is the percentage of firms in a country that reported that they paid at least 2 percent of their revenue to government officials as bribes. ${ }^{21}$ Thus Bribe_Percent is the percentage of firms for which Bribe_Dummy equals one. The external measure, ICRG, is obtained from the International Country Risk Guide, published by Political Risk Services. The variable ICRG ranges from 1 to 6 with a higher number implying more corruption. ${ }^{22}$ The first hybrid measure, KKM, is derived from Kaufman, Kraay and Mastruzzi (2005) and it ranges from 0 to 5 , with a higher number indicating more corruption. ${ }^{23}$ The second hybrid measure, TI, is the Corruption Perception Index, published by Transparency International and it ranges from 1 to 10, where a higher number implies more corruption. ${ }^{24}$ Since our dependent variable is investment growth over the period 1996-1998, we averaged the corruption measures over the period 1995 to 1997 to roughly correspond with the time period when investment decisions were made.

${ }^{21}$ We also run regressions where we used the average score of Bribe_Index for each country as a measure of corruption. The results were qualitatively similar to the results that for Bribe_Percent.

${ }^{22}$ The original data ranged from 1 to 6 , where a higher number implies less corruption. To facilitate the interpretation of the results, we rescaled the data by subtracting the original score from 7 , so that a higher number implies more corruption. The ICRG has been used by many researchers, including Knack and Keefer (1995) and Wei (2000). For more information about the data see http:/www.prsgroup.com/icrg/icrg.html.

${ }^{23}$ The original data from KKM ranged from -2.5 to 2.5 , where a higher number implies less corruption. Similar to the ICRG measure, we rescaled it by subtracting the original KKM score from 2.5 , so that a higher number implies more corruption. The data are available at www.worldbank.org/wbi/governance/govdata/.

${ }^{24}$ The Transparency International corruption perception index are available at http://www.transparency.org/ 
Table 1 shows the correlation matrix for the corruption variables. One noticeable point is that although the measures are taken from different sources, they are highly correlated, all at the at the 1 percent level. This suggests that our corruption measures capture similar attributes, in particular, corruption. Table 2 displays the data for the country-level measures of corruption. It also shows the rank of the countries for each measure of corruption, where a higher rank implies more corruption. The data shows a wide variation in the level of corruption across regions and across countries. Furthermore, the rankings of the countries are generally consistent across the various corruption measures. ${ }^{25}$.Based on both TI and KKM measures, the least corrupt country is Chile $(\mathrm{TI}=3.10$ and $\mathrm{KKM}=1.32)$. For both $\mathrm{TI}$ and $\mathrm{KKM}$, the two most corrupt countries are Nigeria and Azerbaijan: Nigeria ranks last (rank=46) and Azerbaijan ranks next to Nigeria (rank=45) for TI; for KKM, Azerbaijan is the most corrupt country and Nigeria is the second most corrupt.

\section{Control Variables}

We include both firm and country variables that affect firms' investment growth. We employ dummy variables that take on values one or zero to capture the following firm attributes: Small_Firm takes on value 1 if the number of employees is less than 50; Medium_Firm takes on value 1 if the number of employees is greater than 50 and less than 500; Exporter takes on value 1 if a firm is an exporter; Service equals 1 if the firm is in the service industry; Foreign_Owned

\footnotetext{
${ }^{25}$ A few exceptions include Slovenia and Nicaragua. Slovenia ranks very low for KKM and TI (rank=1), and very high for PRS (rank=47). The opposite holds for Nicaragua: it ranks high for KKM (rank=38) and TI (28) but low for PRS (rank=4).
} 
equals 1 if a foreign company has a financial stake in the ownership of the firm; and Govt_Owned equals 1 if the government has a financial stake in the ownership of the firm. ${ }^{26}$

The country control variables are real GDP growth rate (a measure of growth prospects in host countries), inflation rate (a measure of macroeconomic instability) and trade as a share of GDP (a measure of openness to trade). ${ }^{27}$ We hypothesize that firm investment growth is positively related to GDP growth and openness to trade and negatively related to inflation. The data for the country control variables are obtained from the World Development Indicators published by the World Bank. All of the country variables have been employed in previous studies. Similar to the corruption measures, we averaged the country control variables over the period 1995-1998. The summary statistics of the variables are reported in Table 3.

\section{6. $\quad$ Estimation Results}

Our dataset may be problematic in two respects. First, survey data typically tend to have outlier observations due to coding mistakes and/or measurement errors. Second, since most of the data are derived from surveys of firms operating within the same country, it is reasonable to

${ }^{26}$ We used dummy variables to capture firms' trade orientation and foreign ownership because data on the percentage of exports and the percentage of firm ownership was missing for most of the firms in our sample. With regards to firm size, data on assets and sales were also not available for many firms. For these reasons, we used the only other measure of size available from the WBES, which is a simple indicator that categorizes firms as small (5 to 50 employees), medium (51 to 500 employees), and large (more than 500 employees). Batra et al (2003) also use dummy variables to capture firm attributes.

${ }^{27}$ We note that corporate tax rate is likely to affect investment. However, the data was not readily available for most of the countries in our sample. We also experimented with several variables that have been used in previous studies such as political risk, GDP per capita and the level of development of a country's infrastructure. None of these country variables had a significant effect, after controlling for firm characteristics, corruption, and the other country characteristics included in our estimations. 
expect the error terms to be correlated within countries. To handle these potential problems, we employ two types of estimation procedures for our analysis. The first is ordinary least squares (OLS) with heteroskedastic-robust standard errors that allows for clustering within country. Thus, we do not require that error terms be independent across firms within the same country, only that they be independent across countries. The second estimation method is the iteratively re-weighted Least Squares (IRLS). Each of the two procedures has advantages and drawbacks. The main advantage of the OLS procedure with the clustering option is that it is robust to heteroskedasticity as well as correlation among the error terms within clusters. ${ }^{28}$ One caveat, however, is that OLS produces inefficient estimates when a data has significant outliers. ${ }^{29}$ Unlike OLS, IRLS produces robust estimates when a dataset has outlier observations. ${ }^{30}$ The disadvantage, however, is that IRLS assumes independent and identically distributed errors. Thus, none of the two estimation procedures completely addresses the data problems discussed

${ }^{28}$ Our main results hold even when we do not allow for clustering and simply run a standard OLS under the assumption of independent error terms. The estimated coefficients are the same under both procedures, however, the standard errors are higher when we allow for clustering.

${ }^{29}$ An option is to exclude the outlier observations. Doing so, however, can exacerbate biases due to outliers (Bollinger and Chandra, 2003; and Lien and Blalakrishnan, 2005).

${ }^{30}$ We used Stata for our analysis. The iteratively re-weighted least square (IRLS) procedure in Stata calculates weights for each observation using a Huber function, which gives less weight to observations with large residuals, and then performs an iterative weighted least squares. The procedure estimates standard errors and tests hypotheses using methods that do not assume normality. The least absolute deviation or median regressions also mitigate the effect of outliers. However, IRLS is advantageous in the sense that it mitigates the effect of outliers in both the dependent and independent variables, while median regressions reduce the influence of outliers only in the dependent variables. See Hamilton (2004) for more details. 
above. However, together they increase the credibility of any inference we draw from our analysis.

In section 6.1, we analyze how corruption measured at the firm-level affects firm level investment growth (i.e., a micro-analysis). For each measure of corruption, we run regressions with and without country fixed effects and also run regressions for the full sample and subsamples. In addition, we report the results for both OLS and IRLS procedures. In section 6.2, we examine the effect of country-level corruption on investment growth (i.e., a semi-micro analysis) and also investigate whether the effect of corruption on investment differs significantly across regions. In addition, we compare the standardized (beta) coefficients of the corruption variables with the other explanatory variables to determine the importance of corruption vis-à-vis other firm and country characteristics in determining investment growth in Transition countries. Finally, in Section 6.3 we perform some robustness checks and discuss plausible explanations for our results. As pointed out earlier, our objective is to examine the effect of corruption on investment growth. Hence to keep the paper focused, our discussion will focus more on the corruption variables and less on the other independent variables.

\subsection{The Effect of Firm-Level Measures of Corruption on Firm Investment Growth}

The relevant measures of corruption are Bribe_Index, which ranges from 1-6, where a higher number implies a greater amount of bribes paid to government officials, and Bribe_Dummy, which takes on value 1 if a firm reported that at least 2 percent of its revenue was paid to government officials as bribes and zero otherwise.

\subsubsection{Estimations for the Pooled Sample}


We begin our analysis by estimating equation (1) for the pooled sample- i.e., Transition countries and LAC. ${ }^{31}$

$$
\text { INV_GROWTH }_{i j}=\alpha+\beta \text { CORRUPT }_{i j}+\theta \text { FIRM }_{i j}+\gamma \text { COUNTRY }_{j}+\varepsilon_{i j}
$$

where INV_GROWTH ${ }_{i j}$ is the investment growth over the past three years for firm $i$ in country $j$; CORRUPT $_{i j}$ is the firm-level measure of corruption; FIRM $_{i j}$ is a vector of attributes of firm $i$ in country $j$; COUNTRY $j$ is vector of country variables (or country dummy variables for the fixed effects model) ; and $\varepsilon_{i j}$ is the error term. Our parameter of interest is $\beta$, which shows the effect of corruption on firm investment growth.

The results are displayed in Table 4, with the OLS estimates in columns (1)-(4) and IRLS estimates in columns (5)-(8). We first discuss the OLS country fixed effect regressions reported in Columns (1) and (2). Column (1) shows that all else equal, a one level increase in Bribe_Index reduces investment growth by about 2.23 percent. We note that Bribe_Index is an ordinal variable and that it is difficult to interpret the meaning of a one unit increase in the level of corruption reported by a firm. We therefore replace Bribe_Index with the binary measure, Bribe_Dummy. As shown in column (2) the results are qualitatively similar: all else equal, investment growth is about 5.45 percent less for firms that reported paying over 2 percent of their revenue in bribes.

Country fixed effect estimations has the advantage that it controls for the direct impact of all observed and unobserved country characteristics on firm-level investment growth. This approach also addresses any sampling and survey differences that may affect our results. However, country fixed effect estimation precludes one from determining the country characteristics that affect investment. Such an analysis has important policy implications. Thus,

\footnotetext{
${ }^{31}$ Recall that the data on bribery are not available for countries in Sub-Saharan Africa.
} 
in columns (3) and (4) we report the results where we include three country attributes, openness to trade, inflation and GDP growth. Note that the estimated coefficient of Bribe_Index retains its sign and significance. The estimated coefficient of Bribe_Dummy also retains its sign, however, the level of significance drops from 5 percent to 10 percent. The regression results using the IRLS procedure are qualitatively similar to the OLS, albeit with a slightly higher point estimate and better level of significance (columns (5)-(8)). We note that the inverse relationship between firm-level corruption and firm investment growth is consistent with that of Batra et al. (2003).

We now turn our attention to the control variables. The results suggest that overall, investment growth is higher for firms in the service industry and firms that export, but lower for small firms and for firms that have some government ownership. The estimated coefficient of the foreign ownership dummy variable is not significant, suggesting that after controlling for corruption and other firm and country attributes, firm ownership (domestic versus foreign) does not have a significant effect on firm-level investment growth. With regards to the country variables, openness to trade has a positive and significant effect on investment growth. In contrast, inflation and GDP growth do not have a significant impact on investment. The results for the IRLS are qualitatively similar.

\subsubsection{Estimations for Sub-Samples}

The estimation results reported in Table 4 constrains the slope coefficients of the explanatory variables to be the same for LAC and Transition countries. Thus, effectively we are assuming that the effect of corruption and the other explanatory variables on investment growth is similar for the two regions. To examine this issue, we divide the full sample and run separate regressions for LAC and Transition countries. In order to conserve on space and also keep the 
discussion focused, we report the estimated coefficients of the corruption variables in Table 5. Also, to ease comparison, we also report the estimated coefficients of the corruption variables for the pooled sample. The detailed estimation results for LAC and Transition countries are reported in the appendix in Tables A1 and A2, respectively. Two points stand out from Table 5. First, similar to Gaviria (2002) we find that corruption has no significant effect on investment growth for LAC. In contrast, it has a negative and significant effect for Transition countries. Furthermore, the result holds for both the OLS and IRLS procedures. For example, the results for the OLS regressions without country fixed effects indicate that for Transition countries, a one level increase in Bribe_Index reduces investment growth by about 4.14 percent, and that investment growth is about 9.27 percent less for firms that reported paying over 2 percent of their revenue in bribes. The second noticeable point is that the magnitudes of the estimated coefficients of the corruption variables are higher for the pooled sample than for the Transition countries sample. Thus given that corruption has no significant effect on investment growth for LAC, our analysis suggests that the estimates based on the pooled sample overestimates the effect of corruption for LAC and underestimates the effect for Transition countries. Thus, an important implication of this result is that pooling data can produce misleading results. ${ }^{32}$

\footnotetext{
${ }^{32}$ Tables $4 \mathrm{~A}$ and $5 \mathrm{~A}$ in the appendix also reveal that the effects of some of the control variables on investment vary by region. The only control variable that displayed a consistent and similar effect for both regions is a firm's industry affiliation: investment growth is higher for firms in the service sector than for firms in other sectors.
} 


\subsection{The Effect of Country-Level Measures of Corruption on Firm Investment Growth}

The firm-level corruption measures employed in Section 6.1 are advantageous in that

they permit us to examine how a firm's perception of corruption affects the firm's investment decisions. However, the analysis has several drawbacks. First, the measures of corruption reflect only one type of corruption, bribery of government officials. In addition, the data on bribery are not available for countries in SSA. This is problematic because as pointed out earlier, SSA is perceived to be the most corrupt region and also a region that could benefit greatly from an increase in private investment. Another disadvantage is that the estimations have excluded firms that provided information about their investments and other relevant firm attributes but did not answer the question on corruption. The missing bribery data raises a concern about possible selection bias. The third drawback is that the firm-level measures of corruption are internal measures and are thus subject to the limitations of internal measures, such as endogeneity problems, discussed in Section 3.

To mitigate these potential problems, we conduct a semi-micro analysis by replacing the firm-level measure of corruption in equation (1) with the country level measure of corruption. Note that the sample size rises substantially. For example, the number of observations for Transition countries increases from 673 to 1278, an increase of about 90 percent (compare Table 2A and Table 4A in the appendix). Another appealing feature of this approach is that by analyzing the effect of different types of corruption (bribery, embezzlement of fund, nepotism) and also employing measures of corruption from different sources (World Bank, PRS, KKM and TI) and different categories (internal, external and hybrid) we are able to provide a more 
comprehensive analysis of the effect of corruption on investment growth. Finally, the estimations serve as a robustness check for our firm-level, micro analysis. ${ }^{33}$

Table 6 reports the estimated coefficients of the corruption variables for the pooled sample, Transition countries, LAC and SSA. The detailed results are reported in Tables 3A, 4A, 5A and $6 \mathrm{~A}$ in the appendix. The results are consistent with the previous results: the effect of corruption varies by region. Overall, corruption has a negative and significant impact on investment growth for Transition countries but has no significant effect for LAC and SSA. The OLS results indicate that for Transition countries, a one standard deviation increase in corruption will decrease investment growth by about 11.19 percent for the corruption measure Bribe_Percent, by about 3 percent for ICRG, by 9.71 percent for KKM and by about 10.52 percent for TI. Thus, overall, the effect of corruption on investment seems to be consistent across different corruption measures (with the exception of ICRG, which is a little lower than the rest), another indication of the robustness of the results. We use an example to provide the reader with a better sense of the harmful effect of corruption for Transition economies. Consider the corruption measure TI and two countries that are extremely different in terms of corruption Azerbaijan, the most corrupt country in the region and Slovenia, the least corrupt country (see values of TI in Table 3). Then the estimations for the OLS using the corruption measure TI indicate that a decrease in corruption from the level of Azerbaijan (TI=8.3) to the level of Slovenia $(\mathrm{TI}=4.0)$ will on the average, increase investment growth by about 35 percent. ${ }^{34}$

\footnotetext{
${ }^{33}$ Recall that the internal measure Bribe_Percent measures bribery, the external measure ICRG reflects corruption in government such as nepotism and embezzlement of funds, and the hybrid measures TI and KKM reflect bribery as well as other forms of corruption.

${ }^{34}$ The estimated coefficient of TI for the OLS is 8.156. Thus an improvement in the level of corruption from that of Azerbaijan to Slovenia will increase investment growth by $35.07=8.156 *(8.3-4.0)$.
} 


\subsubsection{Does the Effect of Corruption on Investment Growth Differ Significantly Across Regions?}

Our results so far suggest that the effect of corruption on investment varies by region. Below, we examine whether the difference in the estimated coefficients of the corruption measures for the various regions is significantly different from zero. We interact the explanatory variables in equation (1) with the regional dummy variables for LAC and SSA and estimate equation (2):

$$
\begin{array}{r}
\text { INV_GROWTH }=\alpha_{t}+\alpha_{s} \text { SSA }+\alpha_{l} \text { LAC }+\delta_{t} \text { CORRUPT }+\delta_{s} \text { SSA } * \text { CORRUPT }+\delta_{l} \text { LAC } * \text { CORRUPT } \\
+\gamma_{t} \text { CONTROLS }+\gamma_{s} \text { SSA } * \text { CONTROLS }+\gamma_{l} \text { LAC } * \text { CONTROLS }+\varepsilon
\end{array}
$$

Note that $\delta_{l}$ is equal to the difference between the coefficient of corruption for Transition countries and LAC, and $\left(\delta_{l}-\delta_{s}\right)$ is the difference between the coefficient for LAC and SSA. Let $\beta_{t}, \beta_{l}$ and $\beta_{s}$ be the coefficients of the corruption variables for Transition countries, LAC and SSA, respectively. Thus we test the hypothesis $\mathrm{H}_{0}: \beta_{l}-\beta_{t}=0 ; \mathrm{H}_{0}: \beta_{s}-\beta_{t}=0$ and $\mathrm{H}_{0}: \beta_{l}-\beta_{s}=0 .^{35}$ To conserve on space, we report the difference in the estimated coefficients of our parameters of interest in Table 7. The results show that the effect of corruption on investment growth in Transition countries differs significantly from the effect in LAC and SSA; and that the effect for LAC and SSA are similar. This results hold for both OLS and IRLS.

\subsubsection{The Effect of Corruption vis-à-vis Other Explanatory Variables on Investment}

Having ascertained that corruption has a significant effect on investment for Transition countries, we next investigate the relative importance of corruption vis-à-vis other explanatory variables in determining investment growth in the region. We accomplish this by comparing the

\footnotetext{
${ }^{35}$ Note that $\delta_{t}=\beta_{t} ; \delta_{l}=\beta_{l}-\beta_{t} ; \delta_{s}=\beta_{s}-\beta_{t}$ and $\delta_{l}-\delta_{s}=\beta_{l}-\beta_{t}$.
} 
estimated beta coefficients of the regressions. Beta coefficients measure the effect of a variable in standard deviations and are therefore unit-free. Thus, for each regression, the (absolute) magnitude of the beta coefficient determines the relative importance of the variable vis-a-vis other explanatory variables included in the regression. As shown in Table 8, the corruption variables have the highest beta coefficient, suggesting that among the explanatory variables, corruption is the most important determinant of firm-level investment growth - more important than openness to trade, GDP growth, inflation and other firm attributes.

\subsection{Discussion and Robustness Checks}

Our main result is that corruption deters investment in Transition countries but does not have a significant impact on investment growth in SSA and LAC. The insignificant effect of corruption on investments, particularly for SSA, is puzzling and counter-intuitive. In this section we attempt to provide plausible explanations for our results. We first investigated the possibility that the insignificance of corruption may be explained by a lack of variation in the corruption measures for LAC and SSA. Specifically, we examined whether the degree of variability of the corruption measures is substantially lower for LAC and SSA than for Transition countries. We found the opposite. For example, the coefficient of variation of five of the six measures (with the exception is ICRG) is higher for LAC than for Transition countries. Also, the variance and the coefficient of variation for the corruption measure, TI is higher for SSA than for Transition countries.

The second plausible explanation is that there may be severe multicollinearity in the data for LAC and SSA. We tested this by running regressions for LAC and SSA where we included only the corruption measures and firm level control variables and excluded all the country 
control variables (openness to trade, GDP growth and inflation). ${ }^{36}$ None of the corruption measures were significant for SSA. For LAC, only ICRG was significant, the remaining measures were insignificant. We also computed the inverse of the variance inflation factor (IVIF) for each corruption measure. Specifically, we regressed each corruption measure on the other explanatory variables and computed the IVIF $=1-R^{2}$ Thus, the IVIF tells us what proportion of the variance of the corruption variable is independent of all the other explanatory variables. ${ }^{37}$ Overall, the IVIF are high, an indication that multicollinearity is less of a concern. ${ }^{38}$ Another possible explanation could be functional form misspecification. Specifically, it is possible that the relationship between corruption and investment is non-linear. We re-estimated equation (1) where we included the quadratic term for the corruption variable. We also performed a test for joint significance for the corruption measures. Overall, the estimated coefficient of the quadratic term is not significant. Furthermore, in 10 out of the 12 regressions, we fail to reject the hypothesis that the coefficients of the linear and quadratic terms are not jointly significant. In order to conserve on space, we do not report these results.

In summary, our analyses suggest that the insignificance of corruption for LAC and SSA may be explained by factors other than data problems or functional misspecification. We now provide two plausible explanations for our results. First, following the discussion in Section 2, we conjecture that in LAC and SSA, corruption generates private gains to firms and that these gains neutralize the adverse effects of corruption on investment that may result from uncertainty

\footnotetext{
${ }^{36}$ The idea is that the country variables may be correlated with the corruption measures and therefore excluding them will mitigate the multicollinearity problem if it exists.

${ }^{37}$ See Hamilton (2004) for a discussion on using the variance inflation factor to detect multicollinearity.

${ }^{38}$ For example for four out of the five measures of corruption, the IVIF for LAC were substantially higher than that of Transition countries.
} 
or increased operational cost. For the second explanation, we note that our dependent variable is firms' investment growth and therefore our analysis pertains only to firms that are already operating within the country. It is possible that these firms may have factored in the adverse effect of corruption prior to starting their businesses. As a consequence, changes in corruption may have very little effect on the firms' investment decisions.

\section{Conclusion}

Although a number of studies have examined the impact of corruption on aggregate investments, very few have analyzed the effect of corruption on firm-level investments. This paper analyzes the impact of corruption on firm-level investment growth. We find that the effect of corruption varies significantly across regions: corruption has an adverse effect on investment growth for Transition countries, but has no significant effect for Latin America and the Caribbean and Sub-Saharan Africa. Furthermore, among the variables included in the regressions (firm size, firm ownership, trade orientation, industry, GDP growth, inflation and openness to trade) corruption is the most important determinant of investment growth for Transition countries.

Our finding that corruption has no significant effect on investment in Latin America and Sub-Saharan Africa does not imply that corruption is less of a concern in these two regions. A plausible explanation is that corruption provides private rents to some firms. However, these private gains to some firms, do not necessarily translate into social gains. In fact, a number of country-level studies have demonstrated that corruption impedes investments and economic growth (e.g., Mauro, 1995; Pellagrini and Gerlach, 2004), reduces public investments in healthcare, education, and infrastructure (e.g., Tanzi and Davoodi, 1997; Mauro, 1998), and 
results in large social welfare losses (Bose, 2004; Guriev, 2004). Another important point is that our analysis pertains only to firms that are already operating within the country. It is likely that large levels of corruption may prevent many firms from operating in these regions in the first place. However, this loss of potential investments resulting from corruption is not captured by our model. Thus, although corruption does not have a significant effect on investment growth, it is possible, and indeed likely that it might deter the entry of firms. As a consequence, the overall effect of corruption on investment (which includes the loss of potential investments) may be negative. 


\section{References}

Abel, A. B. (1983). Optimal Investment under Uncertainty. The American Economic Review, $73(1), 228-233$.

Abel, A. B., \& Eberly, J. C. (1996). Optimal Investment with Costly Reversibility. The Review of Economic Studies, 63(4), 581-593.

Abel, A. B., Dixit, A. K., Eberly, J. C., \& Pindyck, R. S. (1996). Options, the Value of Capital, and Investment. Quarterly Journal of Economics, 111 (3), 753-777.

Asiedu, E. (2004). Policy Reform and Foreign Direct Investment to Africa: Absolute Progress but Relative Decline. Development Policy Review, 22 (1), 41-48.

Azfar, O., \& Murrell, P. (2005). Identifying Reticent Respondents: Assessing the Quality of Survey Data on Corruption and Values. Working Paper, University of Maryland.

Batra, G., Kaufman, D. \& Stone, A. (2003). Investment Climate Around The World: Voices of the Firms from the World Business Environment Survey. The World Bank: Washington, D.C.

Beck, T., Demirguc-Kunt, A., \& Maksimovic, V. (2005). Financial and Legal Constraint to Growth: Does Firm Size Matter? Journal of Finance, 60 (1), 137 -177.

Bollinger, C. R. \& Chandra, A. (2005). Iatrogenic Specification Errors: A Cautionary Tale of Cleaning Data, Journal of Labor Economics, 23 (2), 235-257.

Bose, G. (2004 ). Bureaucratic Delays and Bribe-Taking. Journal of Economic Behavior and Organization, 54, 313-320.

Boycko, M., Shleifer, A., \& Vishny, R. (1996). A Theory of Privatization. Economic Journal, 106, 309-319. 
Cameron, L., Chaudhuri, A., Erkal, N., \& Gangadharan, L. (2005). Do Attitudes Towards Corruption Differ Across Cultures? Experimental Evidence from Australia, India, Indonesia, and Singapore? Working Paper No. 943. University of Melbourne.

Campo, J. E., Lien, D., \& Pradhan, S. (1999). The Impact of Corruption on Investment: Predictability Matters. World Development, 27 (6), 1059-1067.

Courtney, C. (2002). Corruption in the Official Arms Trade. U.K Transparency International Policy Research Paper 001.

Dixit, A. S. \& Pindyck, R. S. (1994). Investment Under Uncertainty. Princeton, NJ: Princeton University Press.

Ferri, G. (2004). More Analysis, Better Ratings: Do Rating Agencies Invest Enough in Less Developed Countries. Journal of Applied Economics, 7 (1), 77-98.

Fisman, R. \& Svensson, J. (2005). Are Corruption and Taxation Really Harmful to Growth? Firm Level Evidence. Journal of Development Economics. (Forthcoming).

Garrett, T. (2003). Aggregated Versus Disaggregated Data in Regressions Analysis: Implications for Inference. Economic Letters, 81, 61-65.

Gaviria, A. (2002). Assessing the Effects of Corruption and Crime on Firm Performance: Evidence from Latin America. Emerging Markets Review, 3 (3), 245-268.

Guriev, S. (2004). Red Tape and Corruption. Journal of Development Economics, 73, 489-504.

Hall, D. (1999). Privatisation, Multinationals, and Corruption. Public Services International Research Unit (PSIRU) Report.

Hamilton, L. C. (2004). Statistics with STATA. Belmont,CA: Thomson Publishing. 
Hamilton, L. C. (1992b). Quartiles, Outliers, and Normality: Some Monte Carlo Results. In Joseph Hilbe (Ed.) Stata Technical Bulletin Reprints (pp.92-95). College Station, TX: Stata Corp.

Haque, N.U., Nelson, M., \& Matheison, D.J. (2000). Rating Africa: The Economic and Political Content of Risk Indicators. In P. Collier and C. Pattillo (Eds.), Investment and Risk in Africa (pp. 33-70). New York: St Martin's Press.

Hellman, J. S., Jones, G. \& Kaufmann, D. (2003). Seize the State, Seize the Day: State Capture and Influence in Transition Economies. Journal of Comparative Economics, 31 (4), 751773.

Hellman, J. S., Jones, G. \& Kaufmann, D. (2002). "Far From Home: Do Foreign Investors Import Higher Standards of Governance in Transition Economies? World Bank Working Paper. The World Bank, Washington DC.

Hellman, J. S., Jones, G. \& Kaufmann, D. (2006). Far From Home: Do Foreign Investors Import Higher Standards of Governance in Transition Economies? In Corporate Governance and Globalization. Sage Publication Ltd. (Forthcoming).

Kaufman, D., Kraay, A. \& Mastruzzi, M. (2005). Measuring Governance Using Cross-Country Perceptions Data.” World Bank Working Paper. Washington, DC: World Bank.

Kaufmann, D. and Wei,. S. (1999). Does 'Grease Payment' Speed up the Wheels of Commerce. NBER Working Paper 7093.

Knack, S., \& Keefer, P. (1995). Institutions and Economic Performance: Cross-Country Tests Using Alternative Institutional Measures. Economics and Politics, 7 (3), 207-227. 
Lien, D. \& Blalakrishnan, N. (2005). On Regression Analysis with Data Cleaning via Trimming, Winsorization, and Dichotomization. Communications in Statistics-Simulation and Computation, 34, 839-849.

Mauro, P. (1995). Corruption and Growth. Quarterly Journal of Economics, 110, 681-712.

Mauro, P. (1997). The Effect of Corruption on Growth, Investment and Government Expenditure: A Cross-Country Analysis. Corruption and the Global Economy. Institute of International Economics.

McArthur, J., \& Teal, F. (2002 ). Corruption and Firm Performance in Africa. Center for the Study of African Economies (CSAE) Working Paper, 2002/10.

Pellergini, L., \& Gerlagh, R. (2004). Corruption's Effect on Growth and its Transmission Channels. Kyklos, 57 (3), 429-456.

Rock, M. T., \& Bonnet, H. (2004). The Comparative Politics of Corruption: Accounting for the East Asian Paradox in Empirical Studies of Corruption, Growth and Investment. World Development, 32 (6), 999-1017.

Rose_Ackerman, S. (1996). The Political Economy of Corruption: Causes and Consequences. Public Policy for Private Sector. World Bank Note,74.

Shleifer, A., \& Vishny, R. (1993). Corruption. Quarterly Journal of Economics, 108 (3), 599617.

Smarzynska, B. K. \& Wei, S. (2002). Corruption and Cross-Border Investment: Firm-Level Evidence. NBER Working Paper.

Svensson, J. (2003). Who Must Pay Bribes and How Much? Evidence from a Cross-Section of Firms. Quarterly Journal of Economics, 118 (1), 207-229. 
Tanzi, V., \& Davoodi, H. (1997). Corruption, Public Investment and Growth. IMF Working Paper 98/63.

World Investment Report (2000). Cross-border Mergers and Acquisitions and Development. United Nations: New York and Geneva.

Wei, S. (2000). How Taxing is Corruption on International Investors? Review of Economics and Statistics, $82(1), 1-11$.

Wei, S. (2001). Corruption in Economic Transition and Development: Grease or Sand? Mimeo.

Wei, S. (1997). "Why is Corruption so much more Taxing than Tax? Arbitrariness Kills. NBER Working Paper 6255. Cambridge, MA. 


\section{Table 1}

Correlation Matrix of Measures of Corruption

\begin{tabular}{l|lllll}
\hline & Bribe_Index & Bribe_Dummy & Bribe_Percent & ICRG & KKM \\
\hline \multirow{3}{*}{ Bribe_Dummy } & $0.8432^{* * *}$ & & & & \\
& $(0.000)$ & & & \\
Bribe_Percent & $0.4769^{* * *}$ & $0.3335^{* * *}$ & & & \\
& $(0.000)$ & $(0.000)$ & & & \\
ICRG & $0.2482^{* * *}$ & $0.1802^{* * *}$ & $0.4416^{* * *}$ & & \\
& $(0.000)$ & $(0.000)$ & $(0.000)$ & & \\
KKM & $0.2431^{* * *}$ & $0.1774^{* * *}$ & $0.4821^{* * *}$ & $0.4248^{* * *}$ & \\
& $(0.000)$ & $(0.000)$ & $(0.000)$ & $(0.000)$ & \\
TI & $0.2247^{* * *}$ & $0.1651^{* * *}$ & $0.4249^{* * *}$ & $0.4208^{* * *}$ & $0.9450^{* * *}$ \\
& $(0.000)$ & $(0.000)$ & $(0.000)$ & $(0.000)$ & $(0.000)$ \\
\hline
\end{tabular}

Notes: Bribe_Index takes on values 1-6; Bribe_Dummy is equal to 1 if a firm reported that the bribes paid to government officials was greater than or equal to 2 percent of its total revenue, and zero otherwise; Bribe_Percent is the percentage of firms in each country who reported that bribes paid to government officials was greater than or equal to 2 percent of their total revenue; ICRG ranges from 1-6 and is the corruption measure from the International Country Risk Guide; KKM ranges from $0-5$ and is the corruption measure compiled by Kaufman, Kraay and Mastruzzi (2005) and TI is the corruption measure published by Transparency International and it ranges from 1-10. Bribe_Index and Bribe_Dummy are firm-level measures of corruption. Bribe_Index, Bribe_Dummy and Bribe_Percent are internal measures, ICRG is an external measure and KKM and TI are hybrid measures of corruption. For all the corruption measures, a higher number implies more corruption. P-values are in parentheses. * implies significance at $10 \% ; * *$ significance at $5 \% ; * * *$ significance at $1 \%$. 


\section{Table 2}

\section{Country-Level Measures of Corruption for the Countries in the Sample}

\begin{tabular}{|c|c|c|c|c|c|c|c|c|}
\hline Country/Region & \multicolumn{4}{|c|}{ Values of Corruption Measures } & \multicolumn{4}{|c|}{ Rankings of Corruption Measures } \\
\hline Transition & $(1)$ & $(2)$ & $(3)$ & (4) & $(5)$ & (6) & $(7)$ & $(8)$ \\
\hline Countries & Bribe Percent & ICRG & KKM & $\mathrm{TI}$ & Bribe Percent & ICRG & KKM & $\mathrm{TI}$ \\
\hline Armenia & 43.75 & 5.60 & 3.21 & 7.50 & 34 & 52 & 40 & 37 \\
\hline Azerbaijan & 43.68 & 5.60 & 3.51 & 8.30 & 33 & 51 & 52 & 45 \\
\hline Belarus & 22.73 & 4.40 & 3.10 & 6.35 & 16 & 44 & 35 & 18 \\
\hline Croatia & 17.02 & 5.60 & 2.83 & 7.30 & 11 & 50 & 22 & 29 \\
\hline Czech Republic & 39.62 & 2.00 & 2.15 & 5.01 & 31 & 7 & 10 & 8 \\
\hline Estonia & 27.78 & 5.00 & 2.01 & 4.30 & 19 & 46 & 7 & 5 \\
\hline Hungary & 30.95 & 1.00 & 1.81 & 5.13 & 22 & 2 & 4 & 9 \\
\hline Kazakhstan & 38.03 & 5.40 & 3.36 & 7.70 & 29 & 49 & 46 & 39 \\
\hline Romania & 34.18 & 2.78 & 2.88 & 6.75 & 24 & 15 & 24 & 24 \\
\hline Russian Federation & 35.18 & 3.87 & 3.19 & 7.59 & 25 & 38 & 37 & 38 \\
\hline Slovak Republic & 37.50 & 2.45 & 2.58 & 6.20 & 28 & 12 & 15 & 16 \\
\hline Slovenia & 31.71 & 5.2 & 1.67 & 4.00 & 23 & 47 & 2 & 3 \\
\hline Ukraine & 56.69 & 4.8 & 3.39 & 7.30 & 37 & 45 & 47 & 31 \\
\hline
\end{tabular}

Notes: Columns (1)-(4) report the values of the country-level corruption measures. In Columns (5)-(8) the countries are ranked for each measure of corruption. Bribe_Percent is the percentage of firms in each country who reported that bribes paid to government officials was greater than or equal to 2 percent of their total revenue; ICRG ranges from 1-6 and is the corruption measure from the International Country Risk Guide; KKM ranges from 0-5 and is the corruption measure compiled by Kaufman, Kraay and Mastruzzi (2005) and TI is the corruption measure published by Transparency International and it ranges from 1-10. Bribe_Percent is an internal measure, ICRG is an external measure and KKM and TI are hybrid measures of corruption. A higher number implies more corruption. 
Table 2 continued

Measures of Corruption for the Countries in the Sample

\begin{tabular}{|c|c|c|c|c|c|c|c|c|}
\hline Country/Region & \multicolumn{4}{|c|}{ Values of Corruption Measures } & \multicolumn{4}{|c|}{ Rankings of Corruption Measures } \\
\hline $\begin{array}{l}\text { Latin America \& } \\
\text { Caribbean }\end{array}$ & $\begin{array}{c}\text { (1) } \\
\text { Bribe Percent }\end{array}$ & $\begin{array}{c}(2) \\
\text { ICRG }\end{array}$ & $\begin{array}{c}(3) \\
\text { KKM }\end{array}$ & $\begin{array}{l}\text { (4) } \\
\text { TI }\end{array}$ & $\begin{array}{c}\text { (5) } \\
\text { Bribe Percent }\end{array}$ & $\begin{array}{l}\text { (6) } \\
\text { ICRG }\end{array}$ & $\begin{array}{c}(7) \\
\text { KKM }\end{array}$ & $\begin{array}{l}(8) \\
\text { TI }\end{array}$ \\
\hline Argentina & 27.94 & 3.58 & 2.67 & 6.51 & 21 & 35 & 17 & 20 \\
\hline Bolivia & 45.21 & 3.00 & 2.95 & 7.31 & 35 & 22 & 26 & 32 \\
\hline Brazil & 11.43 & 3.00 & 2.39 & 6.54 & 7 & 19 & 13 & 21 \\
\hline Chile & 5.15 & 2.23 & 1.32 & 3.10 & 3 & 10 & 1 & 1 \\
\hline Colombia & 3.30 & 3.90 & 3.09 & 7.3 & 2 & 39 & 34 & 30 \\
\hline Costa Rica & 13.48 & 1.00 & 1.76 & 4.28 & 8 & 1 & 3 & 4 \\
\hline Dominican Rep. & 16.16 & 2.33 & 3.03 & NA & 10 & 11 & 32 & NA \\
\hline Ecuador & 35.90 & 2.83 & 3.27 & 7.37 & 26 & 16 & 43 & 33 \\
\hline El Salvador & 5.43 & 2.47 & 2.81 & 6.25 & 4 & 13 & 21 & 17 \\
\hline Guatemala & 17.65 & 2.60 & 3.21 & 6.85 & 12 & 14 & 39 & 26 \\
\hline Haiti & 43.00 & 3.65 & 3.35 & NA & 32 & 36 & 45 & NA \\
\hline Honduras & 13.64 & 4.00 & 3.22 & 8.25 & 9 & 41 & 41 & 44 \\
\hline Mexico & 27.06 & 3.42 & 2.96 & 6.83 & 18 & 32 & 28 & 25 \\
\hline Nicaragua & 20.00 & 1.62 & 3.20 & 6.95 & 14 & 4 & 38 & 28 \\
\hline Panama & 10.11 & 4.00 & 2.78 & NA & 6 & 40 & 20 & NA \\
\hline Peru & 27.91 & 3.00 & 2.69 & 5.5 & 20 & 21 & 18 & 11 \\
\hline Trinidad \& Tobago & 6.38 & 3.00 & 2.37 & NA & 5 & 18 & 12 & NA \\
\hline Uruguay & 2.67 & 3.00 & 2.08 & 5.72 & 1 & 17 & 8 & 12 \\
\hline Venezuela & 21.33 & 3.00 & 3.23 & 7.43 & 15 & 20 & 42 & 35 \\
\hline \multicolumn{9}{|l|}{ Sub-Saharan Africa } \\
\hline Botswana & NA & 3.00 & 1.97 & 3.90 & NA & 23 & 5 & 2 \\
\hline Cameroon & NA & 3.50 & 3.61 & 8.21 & NA & 34 & 53 & 43 \\
\hline Cote d'Ivoire & NA & 3.40 & 2.85 & NA. & NA & 31 & 23 & NA \\
\hline Ethiopia & NA & 4.00 & 2.75 & NA & NA & 42 & 19 & NA \\
\hline Ghana & NA & 3.38 & 2.94 & 6.70 & NA & 30 & 25 & 23 \\
\hline Kenya & NA & 3.47 & 3.42 & 7.76 & NA & 33 & 49 & 41 \\
\hline Madagascar & NA & 2.00 & 3.30 & NA & NA & 8 & 44 & NA \\
\hline Malawi & NA & 3.00 & 3.00 & 5.90 & NA & 24 & 30 & 14 \\
\hline Namibia & NA & 2.18 & 2.26 & 4.70 & NA & 9 & 11 & 6 \\
\hline Nigeria & NA & 4.30 & 3.50 & 8.51 & NA & 43 & 51 & 46 \\
\hline Senegal & NA & 3.00 & 2.95 & 6.65 & NA & 25 & 27 & 22 \\
\hline South Africa & NA & 1.67 & 2.09 & 4.71 & NA & 5 & 9 & 7 \\
\hline Tanzania & NA & 3.22 & 3.45 & 8.10 & NA & 28 & 50 & 42 \\
\hline Uganda & NA & 3.70 & 3.12 & 7.50 & NA & 37 & 36 & 36 \\
\hline Zambia & NA & 3.00 & 3.06 & 6.50 & NA & 26 & 33 & 19 \\
\hline Zimbabwe & NA & 3.25 & 2.63 & 5.85 & NA & 29 & 16 & 13 \\
\hline
\end{tabular}

Notes: Columns (1)-(4) report the values of the country-level corruption measures. In Columns (5)-(8) the countries are ranked for each measure of corruption. Bribe_Percent is the percentage of firms in each country who reported that bribes paid to government officials was greater than or equal to 2 percent of their total revenue; ICRG ranges from 1-6 and is the corruption measure from the International Country Risk Guide; KKM ranges from 0-5 and is the corruption measure compiled by Kaufman, Kraay and Mastruzzi (2005) and TI is the corruption measure published by Transparency International and it ranges from 1-10. Bribe_Percent is an internal measure, ICRG is an external measure and KKM and TI are hybrid measures of corruption. A higher number implies more corruption. Data on Bribe_Percent are not available for SSA. 


\section{Table 3}

\section{Summary Statistics}

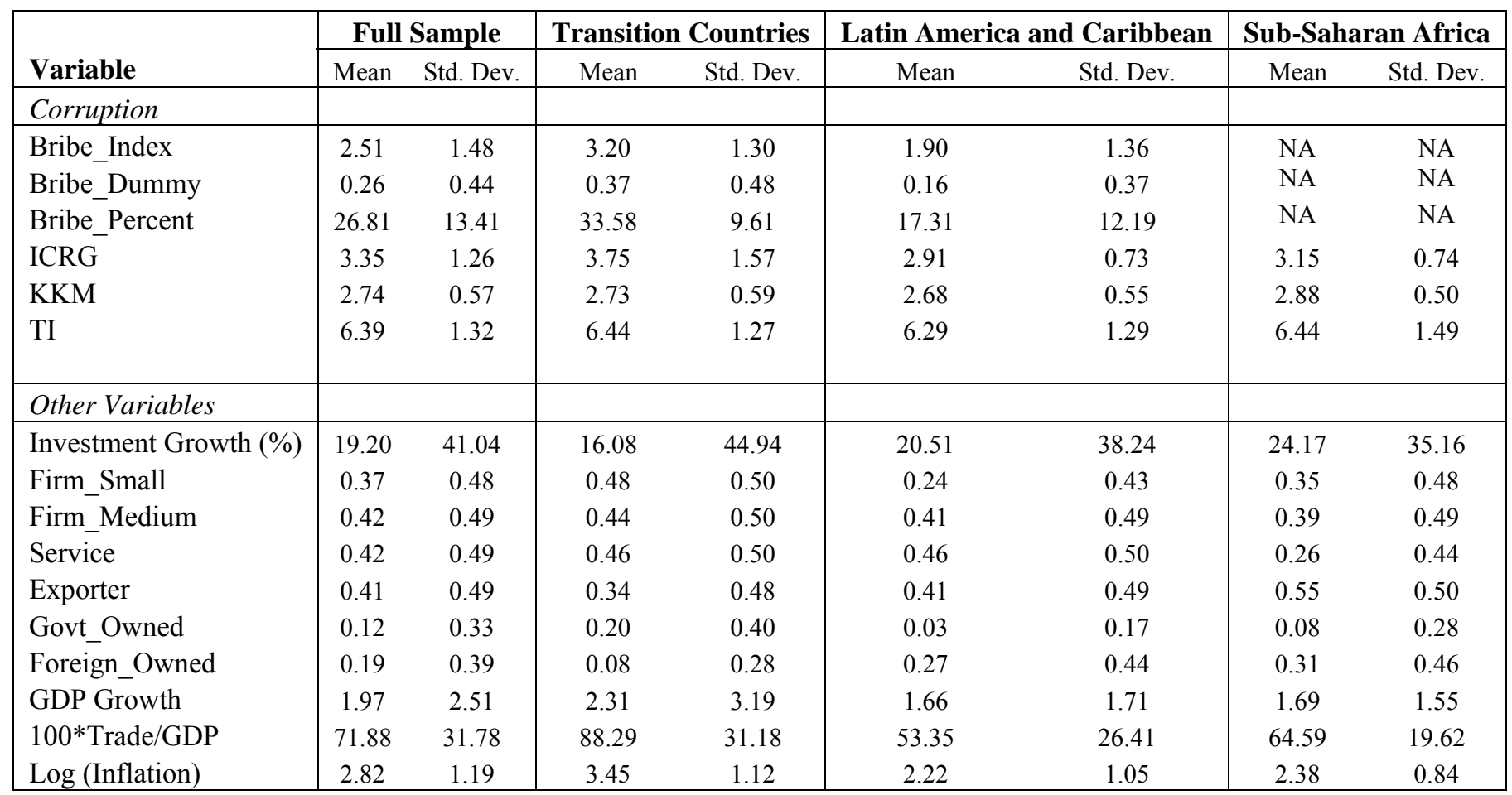

Notes: Columns (1)-(4) report the values of the country-level corruption measures. In Columns (5)-(8) the countries are ranked for each measure of corruption, a higher number implies more corruption. Bribe_Percent is the percentage of firms in each country who reported that bribes paid to government officials was greater than or equal to 2 percent of their total revenue; ICRG ranges from 1-6 and is the corruption measure from the International Country Risk Guide; KKM ranges from 0-5 and is the corruption measure compiled by Kaufman, Kraay and Mastruzzi (2005) and TI is the corruption measure published by Transparency International and it ranges from 1-10. Bribe_Percent is an internal measure, ICRG is an external measure and KKM and TI are hybrid measures of corruption. A higher number implies more corruption. 


\section{Table 4}

Impact of Firm-Level Measures of Corruption on Investment Growth for the Pooled Sample

(Transition and Latin America \& Caribbean)

\begin{tabular}{|c|c|c|c|c|c|c|c|c|}
\hline \multirow{2}{*}{ Variables } & \multicolumn{4}{|c|}{ Ordinary Least Squares } & \multicolumn{4}{|c|}{ Iteratively Re-weighted Least Squares (IRLS) } \\
\hline & $\begin{array}{c}(1) \\
\text { Country Fixed } \\
\text { Effect using } \\
\text { Bribe_Index }\end{array}$ & $\begin{array}{c}\text { (2) } \\
\text { Country Fixed } \\
\text { Effect using } \\
\text { Bribe_Dummy }\end{array}$ & $\begin{array}{l}\text { (3) } \\
\text { Estimations for } \\
\text { Bribe_Index, } \\
\text { Include } \\
\text { Country } \\
\text { Controls }\end{array}$ & $\begin{array}{l}\text { (4) } \\
\text { Estimations for } \\
\text { Bribe_Dummy, } \\
\text { Include } \\
\text { Country } \\
\text { Controls }\end{array}$ & $\begin{array}{c}\text { (5) } \\
\text { Country Fixed } \\
\text { Effect using } \\
\text { Bribe_Index }\end{array}$ & $\begin{array}{c}(6) \\
\text { Country Fixed } \\
\text { Effect using } \\
\text { Bribe_Index }\end{array}$ & $\begin{array}{l}(7) \\
\text { Estimations for } \\
\text { Bribe_Index, } \\
\text { Include } \\
\text { Country } \\
\text { Controls }\end{array}$ & $\begin{array}{l}\text { (8) } \\
\text { Estimations for } \\
\text { Bribe_Dummy, } \\
\text { Include } \\
\text { Country } \\
\text { Controls }\end{array}$ \\
\hline \multicolumn{9}{|l|}{ Corruption } \\
\hline Bribe_Index & $\begin{array}{c}-2.230^{* * *} \\
(0.863)\end{array}$ & & $\begin{array}{c}-2.034 * * \\
(0.970)\end{array}$ & & $\begin{array}{c}-2.237 * * * \\
(0.836)\end{array}$ & & $\begin{array}{c}-2.127 * * * \\
(0.781)\end{array}$ & \\
\hline Bribe_Dummy & & $\begin{array}{c}-5.445^{* *} \\
(2.552)\end{array}$ & & $\begin{array}{c}-5.599 * \\
(2.981)\end{array}$ & & $\begin{array}{c}-5.954^{* *} \\
(2.559)\end{array}$ & & $\begin{array}{c}-5.753^{* *} \\
(2.505)\end{array}$ \\
\hline \multicolumn{9}{|l|}{ Controls } \\
\hline Firm_Small & $\begin{array}{c}-8.271 * * \\
(3.380)\end{array}$ & $\begin{array}{c}-8.735^{* *} \\
(3.420)\end{array}$ & $\begin{array}{c}-8.054 * * * \\
(2.942)\end{array}$ & $\begin{array}{c}-8.757 * * * \\
(2.910)\end{array}$ & $\begin{array}{l}-5.684 \\
(3.480)\end{array}$ & $\begin{array}{l}-6.007 * \\
(3.468)\end{array}$ & $\begin{array}{l}-5.988^{*} \\
(3.349)\end{array}$ & $\begin{array}{c}-6.679 * * \\
(3.318)\end{array}$ \\
\hline Firm_Medium & $\begin{array}{l}-4.944^{*} \\
(2.488)\end{array}$ & $\begin{array}{c}-5.270 * * \\
(2.493)\end{array}$ & $\begin{array}{l}-4.316^{*} \\
(2.534)\end{array}$ & $\begin{array}{l}-4.773 * \\
(2.462)\end{array}$ & $\begin{array}{l}-4.297 \\
(3.052)\end{array}$ & $\begin{array}{l}-4.500 \\
(3.045)\end{array}$ & $\begin{array}{l}-4.070 \\
(2.993)\end{array}$ & $\begin{array}{l}-4.556 \\
(2.980)\end{array}$ \\
\hline Service & $\begin{array}{c}11.316^{* * *} \\
(2.342)\end{array}$ & $\begin{array}{c}11.123 * * * \\
(2.366)\end{array}$ & $\begin{array}{c}10.035^{* * *} \\
(2.386)\end{array}$ & $\begin{array}{c}9.859 * * * \\
(2.421)\end{array}$ & $\begin{array}{c}10.677 * * * \\
(2.242)\end{array}$ & $\begin{array}{c}10.571 * * * \\
(2.241)\end{array}$ & $\begin{array}{c}9.779 * * * \\
(2.238)\end{array}$ & $\begin{array}{c}9.669 * * * \\
(2.238)\end{array}$ \\
\hline Exporter & $\begin{array}{l}7.837 * * \\
(2.985)\end{array}$ & $\begin{array}{c}7.780^{* *} \\
(2.978)\end{array}$ & $\begin{array}{c}8.302 * * * \\
(2.912)\end{array}$ & $\begin{array}{c}8.273^{* * * *} \\
(2.894)\end{array}$ & $\begin{array}{c}7.109 * * * \\
(2.519)\end{array}$ & $\begin{array}{c}6.991 * * * \\
(2.519)\end{array}$ & $\begin{array}{c}7.792 * * * \\
(2.483)\end{array}$ & $\begin{array}{c}7.710 * * * \\
(2.486)\end{array}$ \\
\hline Govt_Owned & $\begin{array}{c}-16.766^{* * * *} \\
(4.524)\end{array}$ & $\begin{array}{c}-16.547 * * * \\
(4.510)\end{array}$ & $\begin{array}{c}-16.798 * * * \\
(4.728)\end{array}$ & $\begin{array}{c}-16.955^{* * *} \\
(4.688)\end{array}$ & $\begin{array}{c}-15.547 * * * \\
(4.124)\end{array}$ & $\begin{array}{c}-15.308 * * * \\
(4.123)\end{array}$ & $\begin{array}{c}-14.703 * * * \\
(4.057)\end{array}$ & $\begin{array}{c}-14.798 * * * \\
(4.059)\end{array}$ \\
\hline Foreign_Owned & $\begin{array}{c}4.562 \\
(3.653)\end{array}$ & $\begin{array}{c}4.706 \\
(3.696)\end{array}$ & $\begin{array}{c}4.602 \\
(3.437)\end{array}$ & $\begin{array}{c}4.817 \\
(3.480)\end{array}$ & $\begin{array}{c}3.788 \\
(2.970)\end{array}$ & $\begin{array}{c}3.819 \\
(2.968)\end{array}$ & $\begin{array}{c}3.987 \\
(2.961)\end{array}$ & $\begin{array}{c}4.156 \\
(2.960)\end{array}$ \\
\hline GDP Growth & & & $\begin{array}{c}0.675 \\
(1.000)\end{array}$ & $\begin{array}{c}0.653 \\
(0.992)\end{array}$ & & & $\begin{array}{c}0.805 \\
(0.493)\end{array}$ & $\begin{array}{c}0.781 \\
(0.495)\end{array}$ \\
\hline $100 *$ Trade/GDP & & & $\begin{array}{c}0.108 * * \\
(0.050)\end{array}$ & $\begin{array}{c}0.103 * * \\
(0.048)\end{array}$ & & & $\begin{array}{c}0.079 * * \\
(0.037)\end{array}$ & $\begin{array}{c}0.074 * * \\
(0.036)\end{array}$ \\
\hline Log (Inflation) & & & $\begin{array}{l}-0.607 \\
(1.497)\end{array}$ & $\begin{array}{l}-0.951 \\
(1.533)\end{array}$ & & & $\begin{array}{c}-0.952 \\
(1.021)\end{array}$ & $\begin{array}{l}-1.302 \\
(1.008)\end{array}$ \\
\hline Constant & $\begin{array}{c}21.298^{* * *} \\
(3.679)\end{array}$ & $\begin{array}{c}17.490 * * * \\
(2.765)\end{array}$ & $\begin{array}{c}13.966^{* * *} \\
(5.150)\end{array}$ & $\begin{array}{c}12.207^{* *} \\
(4.740)\end{array}$ & $\begin{array}{c}14.875^{* *} \\
(7.391)\end{array}$ & $\begin{array}{l}12.186^{*} \\
(7.246)\end{array}$ & $\begin{array}{c}15.535^{* * *} \\
(4.401)\end{array}$ & $\begin{array}{c}13.631^{* * *} \\
(4.326)\end{array}$ \\
\hline No. of Firms & 1434 & 1434 & 1434 & 1434 & 1434 & 1434 & 1434 & 1434 \\
\hline No. of Countries & 37 & 37 & 37 & 37 & 37 & 37 & 37 & 37 \\
\hline
\end{tabular}

Notes: Bribe_Index takes on values 1-6 and Bribe_Dummy is equal to 1 if a firm reported that the bribes paid to government officials was greater than or equal to 2 percent of its total revenue, and zero otherwise. Standard errors are in parentheses. 
Table 5

Effect of Firm-Level Measures of Corruption on Firm-Level Investment Growth

\begin{tabular}{|c|c|c|c|c|c|c|c|}
\hline \multirow[t]{2}{*}{ Corruption Variables } & \multirow{2}{*}{$\begin{array}{l}\text { Country } \\
\text { Fixed } \\
\text { Effects? }\end{array}$} & \multicolumn{2}{|c|}{ Pooled Sample } & \multicolumn{2}{|c|}{ Transition Countries } & \multicolumn{2}{|c|}{ Latin America } \\
\hline & & OLS & IRLS & OLS & IRLS & OLS & IRLS \\
\hline Bribe_Index & Yes & $\begin{array}{c}-2.230^{* *} \\
(0.863)\end{array}$ & $\begin{array}{c}-2.237 * * * \\
(0.836)\end{array}$ & $\begin{array}{c}-3.148^{* *} \\
(1.472)\end{array}$ & $\begin{array}{c}-3.335^{* *} \\
(1.324)\end{array}$ & $\begin{array}{l}-1.485 \\
(1.030)\end{array}$ & $\begin{array}{l}-1.174 \\
(1.060)\end{array}$ \\
\hline Bribe_Dummy & Yes & $\begin{array}{c}-5.445^{* *} \\
(2.552)\end{array}$ & $\begin{array}{c}-5.954 * * \\
(2.559)\end{array}$ & $\begin{array}{c}-7.415^{*} \\
(3.631)\end{array}$ & $\begin{array}{c}-8.775^{* *} \\
(3.507)\end{array}$ & $\begin{array}{l}-3.341 \\
(3.703)\end{array}$ & $\begin{array}{l}-2.366 \\
(3.853)\end{array}$ \\
\hline Bribe_Index & No & $\begin{array}{c}-2.034^{* *} \\
(0.970)\end{array}$ & $\begin{array}{c}-2.127 * * * \\
(0.781)\end{array}$ & $\begin{array}{c}-4.144^{* *} \\
(1.807)\end{array}$ & $\begin{array}{c}-4.561 * * * \\
(1.353)\end{array}$ & $\begin{array}{l}-0.776 \\
(1.004)\end{array}$ & $\begin{array}{l}-0.477 \\
(0.987)\end{array}$ \\
\hline Bribe_Dummy & No & $\begin{array}{c}-5.599 * \\
(2.981)\end{array}$ & $\begin{array}{c}-5.753^{* *} \\
(2.505)\end{array}$ & $\begin{array}{c}-9.270 * * \\
(4.264)\end{array}$ & $\begin{array}{c}-10.618^{* * *} \\
(3.614)\end{array}$ & $\begin{array}{l}-1.374 \\
(3.409)\end{array}$ & $\begin{array}{l}-0.341 \\
(3.642)\end{array}$ \\
\hline
\end{tabular}

Notes: Bribe_Index takes on values 1-6 and Bribe_Dummy is equal to 1 if a firm reported that the bribes paid to government officials was greater than or equal to 2 percent of its total revenue, and zero otherwise. Standard errors are in parentheses. * implies significance at $10 \%$; $* *$ significance at $5 \%$; $* * *$ significance at $1 \%$. We do not include SSA because data on briery are not available for countries in the region. 


\section{Table 6}

Effect of Country-Level Measures of Corruption on Firm-Level Investment Growth

\begin{tabular}{|c|c|c|c|c|c|c|c|c|}
\hline \multirow{2}{*}{$\begin{array}{l}\text { Corruption } \\
\text { Variables }\end{array}$} & \multicolumn{2}{|c|}{ Pooled Sample } & \multicolumn{2}{|c|}{ Transition Countries } & \multicolumn{2}{|c|}{ Latin America } & \multicolumn{2}{|c|}{ Sub-Saharan Africa } \\
\hline & OLS & IRLS & OLS & IRLS & OLS & IRLS & OLS & IRLS \\
\hline Bribe_Percent & $\begin{array}{c}-0.146 \\
(0.165)\end{array}$ & $\begin{array}{c}-0.180^{* *} \\
(0.079)\end{array}$ & $\begin{array}{c}-0.918^{* *} \\
(0.408)\end{array}$ & $\begin{array}{c}-1.018^{* * *} \\
(0.174)\end{array}$ & $\begin{array}{c}0.150 \\
(0.096)\end{array}$ & $\begin{array}{c}0.146 \\
(0.103)\end{array}$ & $\begin{array}{l}\text { NA } \\
\text { NA }\end{array}$ & $\begin{array}{l}\text { NA } \\
\text { NA }\end{array}$ \\
\hline ICRG & $\begin{array}{c}-3.499 * * \\
(1.487)\end{array}$ & $\begin{array}{c}-3.677 * * * \\
(0.611)\end{array}$ & $\begin{array}{c}-4.158^{* * *} \\
(1.870)\end{array}$ & $\begin{array}{c}-4.468 * * * \\
(0.838)\end{array}$ & $\begin{array}{l}-1.483 \\
(2.089)\end{array}$ & $\begin{array}{l}-1.622 \\
(2.277)\end{array}$ & $\begin{array}{c}1.403 \\
(1.741)\end{array}$ & $\begin{array}{c}0.910 \\
(1.414)\end{array}$ \\
\hline KKM & $\begin{array}{c}-5.226 \\
(3.393) \\
\end{array}$ & $\begin{array}{c}-4.872 * * * \\
(1.542) \\
\end{array}$ & $\begin{array}{c}-17.649 * * * \\
(5.404)\end{array}$ & $\begin{array}{c}-18.664 * * * \\
(2.920)\end{array}$ & $\begin{array}{l}4.160^{*} \\
(2.134) \\
\end{array}$ & $\begin{array}{l}4.473^{*} \\
(2.615)\end{array}$ & $\begin{array}{c}-0.612 \\
(2.195) \\
\end{array}$ & $\begin{array}{l}-0.567 \\
(2.222) \\
\end{array}$ \\
\hline $\mathrm{TI}$ & $\begin{array}{c}-2.998^{* *} \\
(1.443)\end{array}$ & $\begin{array}{c}-2.784 * * * \\
(0.739)\end{array}$ & $\begin{array}{c}-8.158^{* * * *} \\
(2.166)\end{array}$ & $\begin{array}{c}-8.759 * * * \\
(1.352)\end{array}$ & $\begin{array}{l}2.346^{*} \\
(1.221)\end{array}$ & $\begin{array}{c}2.419 \\
(2.201)\end{array}$ & $\begin{array}{c}-0.033 \\
(0.835)\end{array}$ & $\begin{array}{l}-0.197 \\
(0.846)\end{array}$ \\
\hline
\end{tabular}

Notes: IRLS refers to iteratively re-weighted least squares. Bribe Percent is the percentage of firms in each country who reported that bribes paid to government officials was greater than or equal to 2 percent of their total revenue; ICRG ranges from 1-6 and is the corruption measure from the International Country Risk Guide; KKM ranges from 0-5 and is the corruption measure compiled by Kaufman, Kraay and Mastruzzi (2005) and TI is the corruption measure published by Transparency International and it ranges from 1-10. Bribe_Percent is an internal measure, ICRG is an external measure and KKM and TI are hybrid measures of corruption. A higher number implies more corruption. Standard errors are in parenthesis. 
Table 7

Differences in the Estimated Coefficient of Corruption

\begin{tabular}{|c|c|c|c|c|c|c|}
\hline \multirow[b]{2}{*}{ Corruption Variable } & \multicolumn{3}{|c|}{ Ordinary Least Square } & \multicolumn{3}{|c|}{ Iteratively Re-weighted Least Squares } \\
\hline & $\begin{array}{c}\text { Transition versus } \\
\text { Latin America } \\
\beta_{l}-\beta_{t}\end{array}$ & $\begin{array}{c}\text { Transition versus } \\
\text { SSA } \\
\beta_{s}-\beta_{t}\end{array}$ & $\begin{array}{c}\text { SSA versus Latin } \\
\text { America } \\
\beta_{l}-\beta_{s}\end{array}$ & $\begin{array}{c}\text { Transition versus } \\
\text { Latin America } \\
\beta_{l}-\beta_{t}\end{array}$ & $\begin{array}{c}\text { Transition versus } \\
\text { SSA } \\
\beta_{s}-\beta_{t}\end{array}$ & $\begin{array}{c}\text { SSA versus Latin } \\
\text { America } \\
\beta_{l}-\beta_{s}\end{array}$ \\
\hline Bribe_Percent & $\begin{array}{l}1.068^{* *} \\
(0.014)\end{array}$ & NA & NA & $\begin{array}{c}1.194 * * * \\
(0.000)\end{array}$ & $\mathrm{NA}$ & $\mathrm{NA}$ \\
\hline ICRG & $\begin{array}{c}2.675 \\
(0.336)\end{array}$ & $\begin{array}{c}5.561^{* *} \\
(0.031)\end{array}$ & $\begin{array}{l}-2.886 \\
(0.284)\end{array}$ & $\begin{array}{c}2.916 \\
(0.248)\end{array}$ & $\begin{array}{c}4.758^{* *} \\
(0.048)\end{array}$ & $\begin{array}{l}-1.842 \\
(0.580)\end{array}$ \\
\hline KKM & $\begin{array}{c}21.809^{* * * *} \\
(0.000)\end{array}$ & $\begin{array}{c}17.036^{* * * *} \\
(0.004)\end{array}$ & $\begin{array}{c}4.773 \\
(0.117)\end{array}$ & $\begin{array}{c}23.268^{* * *} \\
(0.000)\end{array}$ & $\begin{array}{c}17.915^{* * *} \\
(0.000)\end{array}$ & $\begin{array}{c}5.353 \\
(0.239)\end{array}$ \\
\hline $\mathrm{TI}$ & $\begin{array}{c}10.504 * * * \\
(0.000)\end{array}$ & $\begin{array}{c}8.125^{* * * *} \\
(0.001)\end{array}$ & $\begin{array}{c}2.379 \\
(0.105)\end{array}$ & $\begin{array}{c}11.351 * * * \\
(0.000)\end{array}$ & $\begin{array}{c}8.542 * * * \\
(0.000)\end{array}$ & $\begin{array}{c}2.809 \\
(0.294)\end{array}$ \\
\hline
\end{tabular}

Bribe_Percent is the percentage of firms in each country who reported that bribes paid to government officials was greater than or equal to 2 percent of their total revenue; ICRG ranges from 1-6 and is the corruption measure from the International Country Risk Guide; KKM ranges from 0-5 and is the corruption measure compiled by Kaufman, Kraay and Mastruzzi (2005) and TI is the corruption measure published by Transparency International and it ranges from 1-10. Bribe_Percent is an internal measure, ICRG is an external measure and KKM and TI are hybrid measures of corruption. A higher number implies more corruption. P-values are in parenthesis. 


\section{Table 8}

Impact of Corruption on Investment Growth for Transition Countries: Estimated Standardized (Beta) Coefficients

\begin{tabular}{|l|c|c|c|c|}
\hline Variables & Bribe_Percent & ICRG & KKM & TI \\
\hline Corruption & $\mathbf{- 0 . 1 9 6}$ & $\mathbf{- 0 . 1 4 6}$ & $\mathbf{- 0 . 2 3 3}$ & $\mathbf{- 0 . 2 3 1}$ \\
Firm_Small & 0.115 & 0.092 & 0.091 & 0.087 \\
Firm_Medium & 0.055 & 0.058 & 0.044 & 0.039 \\
Service & 0.088 & 0.082 & 0.084 & 0.083 \\
Exporter & 0.140 & 0.142 & 0.126 & 0.124 \\
Govt_Owned & -0.062 & -0.057 & -0.058 & -0.056 \\
Foreign_Owned & -0.131 & -0.005 & -0.003 & -0.007 \\
GDP Growth & 0.002 & 0.006 & -0.033 & -0.045 \\
100*Trade/GDP & 0.002 & 0.030 & -0.072 & -0.104 \\
Log(Inflation) & -0.125 & -0.064 & 0.022 & -0.022 \\
\hline
\end{tabular}




\section{Appendix}

Table 1A

Effect of Firm-Level Measures of Corruption on Investment Growth: Transition Countries

\begin{tabular}{|c|c|c|c|c|c|c|c|c|}
\hline \multirow{2}{*}{$\begin{array}{l}\text { Variables } \\
\text { Corruption }\end{array}$} & \multicolumn{4}{|c|}{ Ordinary Least Squares } & \multicolumn{4}{|c|}{ Iteratively Re-weighted Least Squares (IRLS) } \\
\hline & & & & & & & & \\
\hline Bribe_Index & $\begin{array}{l}-3.148^{* *} \\
(1.472) \\
\end{array}$ & & $\begin{array}{l}-4.144 * * \\
(1.807) \\
\end{array}$ & & $\begin{array}{l}-3.335^{* *} \\
(1.324) \\
\end{array}$ & & $\begin{array}{l}-4.561 * * * \\
(1.353)\end{array}$ & \\
\hline Bribe_Dummy & & $\begin{array}{l}-7.415^{*} \\
(3.631)\end{array}$ & & $\begin{array}{l}-9.270^{* *} \\
(4.264)\end{array}$ & & $\begin{array}{l}-8.775^{* *} \\
(3.507)\end{array}$ & & $\begin{array}{l}-10.618^{* * * *} \\
(3.614)\end{array}$ \\
\hline \multicolumn{9}{|l|}{ Controls } \\
\hline Firm_Small & $\begin{array}{l}-1.954 \\
(9.373) \\
\end{array}$ & $\begin{array}{l}-1.952 \\
(9.677) \\
\end{array}$ & $\begin{array}{l}-0.795 \\
(9.142) \\
\end{array}$ & $\begin{array}{l}-0.827 \\
(9.283) \\
\end{array}$ & $\begin{array}{l}-0.881 \\
(8.147) \\
\end{array}$ & $\begin{array}{l}-0.208 \\
(8.151) \\
\end{array}$ & $\begin{array}{l}1.263 \\
(8.373) \\
\end{array}$ & $\begin{array}{l}1.380 \\
(8.403)\end{array}$ \\
\hline Firm_Medium & $\begin{array}{l}-7.328 \\
(8.762)\end{array}$ & $\begin{array}{l}-7.245 \\
(8.887)\end{array}$ & $\begin{array}{l}-6.151 \\
(8.559)\end{array}$ & $\begin{array}{l}-6.051 \\
(8.586)\end{array}$ & $\begin{array}{l}-7.237 \\
(7.505)\end{array}$ & $\begin{array}{l}-6.635 \\
(7.506)\end{array}$ & $\begin{array}{l}-5.614 \\
(7.782)\end{array}$ & $\begin{array}{l}-5.520 \\
(7.806)\end{array}$ \\
\hline Service & $\begin{array}{l}6.992^{*} \\
(3.337)\end{array}$ & $\begin{array}{l}6.613^{*} \\
(3.428)\end{array}$ & $\begin{array}{l}6.073 \\
(3.778)\end{array}$ & $\begin{array}{l}5.556 \\
(3.896)\end{array}$ & $\begin{array}{l}8.037^{* * *} \\
(3.588)\end{array}$ & $\begin{array}{l}7.661^{* *} \\
(3.592)\end{array}$ & $\begin{array}{l}6.925^{*} \\
(3.720)\end{array}$ & $\begin{array}{l}6.332^{*} \\
(3.733)\end{array}$ \\
\hline Exporter & $\begin{array}{l}12.116^{* *} \\
(4.631)\end{array}$ & $\begin{array}{l}12.247 * * \\
(4.538)\end{array}$ & $\begin{array}{l}14.707 * * * \\
(4.606)\end{array}$ & $\begin{array}{l}14.873 * * * \\
(4.560)\end{array}$ & $\begin{array}{l}9.973 * * \\
(4.332)\end{array}$ & $\begin{array}{l}9.963 * * \\
(4.330)\end{array}$ & $\begin{array}{l}13.637 * * * \\
(4.377)\end{array}$ & $\begin{array}{l}13.702 * * * \\
(4.388)\end{array}$ \\
\hline Govt_Owned & $\begin{array}{l}-17.641^{* * * *} \\
(5.291)\end{array}$ & $\begin{array}{l}-17.341 * * * \\
(5.232)\end{array}$ & $\begin{array}{l}-18.399 * * * \\
(5.486)\end{array}$ & $\begin{array}{l}-18.112^{* * * *} \\
(5.419)\end{array}$ & $\begin{array}{l}-16.214^{* * * *} \\
(5.331)\end{array}$ & $\begin{array}{l}-15.803 * * * \\
(5.331)\end{array}$ & $\begin{array}{l}-15.762^{* * * *} \\
(5.518)\end{array}$ & $\begin{array}{l}-15.369 * * * \\
(5.535)\end{array}$ \\
\hline Foreign_Owned & $\begin{array}{l}-0.603 \\
(5.493)\end{array}$ & $\begin{array}{l}-0.537 \\
(5.500)\end{array}$ & $\begin{array}{l}1.251 \\
(4.900)\end{array}$ & $\begin{array}{l}1.488 \\
(4.909)\end{array}$ & $\begin{array}{l}-3.093 \\
(6.355)\end{array}$ & $\begin{array}{l}-3.311 \\
(6.353)\end{array}$ & $\begin{array}{l}-1.204 \\
(6.453)\end{array}$ & $\begin{array}{l}-1.204 \\
(6.469)\end{array}$ \\
\hline GDP Growth & & & $\begin{array}{l}-0.450 \\
(1.255) \\
\end{array}$ & $\begin{array}{l}-0.342 \\
(1.255) \\
\end{array}$ & & & $\begin{array}{l}-0.195 \\
(0.731) \\
\end{array}$ & $\begin{array}{l}-0.122 \\
(0.730) \\
\end{array}$ \\
\hline $100 *$ Trade/GDP & & & $\begin{array}{l}0.051 \\
(0.085) \\
\end{array}$ & $\begin{array}{l}0.049 \\
(0.086) \\
\end{array}$ & & & $\begin{array}{l}0.040 \\
(0.058) \\
\end{array}$ & $\begin{array}{l}0.038 \\
(0.058) \\
\end{array}$ \\
\hline Log (Inflation) & & & $\begin{array}{l}-2.593 \\
(3.631) \\
\end{array}$ & $\begin{array}{l}-2.679 \\
(3.697) \\
\end{array}$ & & & $\begin{array}{l}-2.542 \\
(2.255) \\
\end{array}$ & $\begin{array}{l}-2.763 \\
(2.263) \\
\end{array}$ \\
\hline Constant & $\begin{array}{l}25.127^{* *} \\
(11.165)\end{array}$ & $\begin{array}{l}17.862^{*} \\
(8.878) \\
\end{array}$ & $\begin{array}{l}32.668 \\
(22.645) \\
\end{array}$ & $\begin{array}{l}23.172 \\
(20.730) \\
\end{array}$ & $\begin{array}{l}44.165^{* *} \\
(20.134) \\
\end{array}$ & $\begin{array}{l}35.552^{*} \\
(19.613)\end{array}$ & $\begin{array}{l}31.709^{* *} \\
(14.179)\end{array}$ & $\begin{array}{l}22.063 \\
(13.626) \\
\end{array}$ \\
\hline $\begin{array}{l}\text { Country Fixed } \\
\text { Effects? }\end{array}$ & Yes & Yes & No & No & Yes & Yes & No & No \\
\hline No. of Firms & 673 & 673 & 673 & 673 & 673 & 673 & 673 & 673 \\
\hline No. of Countries & 18 & 18 & 18 & 18 & 18 & 18 & 18 & 18 \\
\hline
\end{tabular}


Table 2A

Effect of Firm-Level Measures of Corruption on Investment Growth: Latin America \& Caribbean

\begin{tabular}{|c|c|c|c|c|c|c|c|c|}
\hline \multirow{2}{*}{$\frac{\text { Variables }}{\text { Corruption }}$} & \multicolumn{4}{|c|}{ Ordinary Least Squares } & \multicolumn{4}{|c|}{ Iteratively Re-weighted Least Squares (IRLS) } \\
\hline & & & & & & & & \\
\hline Bribe_Index & $\begin{array}{l}-1.485 \\
(1.030)\end{array}$ & & $\begin{array}{l}-0.776 \\
(1.004)\end{array}$ & & $\begin{array}{l}-1.174 \\
(1.060)\end{array}$ & & $\begin{array}{l}-0.477 \\
(0.987)\end{array}$ & \\
\hline Bribe_Dummy & & $\begin{array}{l}-3.341 \\
(3.703)\end{array}$ & & $\begin{array}{l}-1.374 \\
(3.409)\end{array}$ & & $\begin{array}{l}-2.366 \\
(3.853)\end{array}$ & & $\begin{array}{l}-0.341 \\
(3.642)\end{array}$ \\
\hline \multicolumn{9}{|l|}{ Controls } \\
\hline Firm_Small & $\begin{array}{l}-13.587 * * * \\
(3.924)\end{array}$ & $\begin{array}{l}-14.007 * * * \\
(3.960)\end{array}$ & $\begin{array}{l}-15.296^{* * *} \\
(3.633)\end{array}$ & $\begin{array}{l}-15.570^{* * *} \\
(3.758)\end{array}$ & $\begin{array}{l}-10.930 * * * \\
(3.850)\end{array}$ & $\begin{array}{l}-11.139 * * * \\
(3.832)\end{array}$ & $\begin{array}{l}-13.119 * * * \\
(3.659)\end{array}$ & $\begin{array}{l}-13.301 * * * \\
(3.639)\end{array}$ \\
\hline Firm_Medium & $\begin{array}{l}-1.280 \\
(2.562)\end{array}$ & $\begin{array}{l}-1.552 \\
(2.574)\end{array}$ & $\begin{array}{l}-2.378 \\
(2.819)\end{array}$ & $\begin{array}{l}-2.543 \\
(2.843)\end{array}$ & $\begin{array}{l}-0.428 \\
(3.288)\end{array}$ & $\begin{array}{l}-0.557 \\
(3.281)\end{array}$ & $\begin{array}{l}-1.876 \\
(3.150)\end{array}$ & $\begin{array}{l}-1.990 \\
(3.145)\end{array}$ \\
\hline Service & $\begin{array}{l}12.821 * * * \\
(2.998)\end{array}$ & $\begin{array}{l}12.701^{* * *} \\
(3.019)\end{array}$ & $\begin{array}{l}11.873^{* * * *} \\
(3.122)\end{array}$ & $\begin{array}{l}11.805^{* * *} \\
(3.137)\end{array}$ & $\begin{array}{l}10.549^{* * * *} \\
(2.872)\end{array}$ & $\begin{array}{l}10.472 * * * \\
(2.871)\end{array}$ & $\begin{array}{l}9.820 * * * \\
(2.816)\end{array}$ & $\begin{array}{l}9.831 * * * \\
(2.814)\end{array}$ \\
\hline Exporter & $\begin{array}{l}6.574 * \\
(3.725)\end{array}$ & $\begin{array}{l}6.502 * \\
(3.743)\end{array}$ & $\begin{array}{l}5.613 \\
(3.554)\end{array}$ & $\begin{array}{l}5.611 \\
(3.562)\end{array}$ & $\begin{array}{l}6.715^{* *} \\
(3.042)\end{array}$ & $\begin{array}{l}6.636^{* *} \\
(3.042)\end{array}$ & $\begin{array}{l}5.540 * \\
(2.961)\end{array}$ & $\begin{array}{l}5.520 * \\
(2.961)\end{array}$ \\
\hline Govt_Owned & $\begin{array}{l}-3.556 \\
(6.337)\end{array}$ & $\begin{array}{l}-3.219 \\
(6.203)\end{array}$ & $\begin{array}{l}-6.928 \\
(5.824)\end{array}$ & $\begin{array}{l}-6.722 \\
(5.733)\end{array}$ & $\begin{array}{l}-2.591 \\
(7.786)\end{array}$ & $\begin{array}{l}-2.329 \\
(7.782)\end{array}$ & $\begin{array}{l}-5.865 \\
(7.572)\end{array}$ & $\begin{array}{l}-5.754 \\
(7.566)\end{array}$ \\
\hline Foreign_Owned & $\begin{array}{l}6.335 \\
(4.566)\end{array}$ & $\begin{array}{l}6.476 \\
(4.692)\end{array}$ & $\begin{array}{l}6.039 \\
(4.504)\end{array}$ & $\begin{array}{l}6.138 \\
(4.602)\end{array}$ & $\begin{array}{l}5.750^{*} \\
(3.197)\end{array}$ & $\begin{array}{l}5.792 * \\
(3.199)\end{array}$ & $\begin{array}{l}5.699 * \\
(3.110)\end{array}$ & $\begin{array}{l}5.767 * \\
(3.110)\end{array}$ \\
\hline GDP Growth & & & $\begin{array}{l}2.333 * * * \\
(0.794)\end{array}$ & $\begin{array}{l}2.360 * * * \\
(0.772)\end{array}$ & $\begin{array}{l}2.851^{* * *} \\
(1.449)\end{array}$ & & & $\begin{array}{l}1.634^{*} \\
(0.897)\end{array}$ \\
\hline $100 *$ Trade/GDP & & & $\begin{array}{l}0.099 \\
(0.058)\end{array}$ & $\begin{array}{l}0.100^{*} \\
(0.057)\end{array}$ & $\begin{array}{l}0.192 \\
(0.129)\end{array}$ & & & $\begin{array}{l}0.097 * \\
(0.056)\end{array}$ \\
\hline Log (Inflation) & & & $\begin{array}{l}-0.668 \\
(1.059)\end{array}$ & $\begin{array}{l}-0.693 \\
(1.058)\end{array}$ & $\begin{array}{l}-4.057^{*} \\
(2.440)\end{array}$ & & & $\begin{array}{l}-1.179 \\
(1.345)\end{array}$ \\
\hline Constant & $\begin{array}{l}16.673 * * * \\
(4.003)\end{array}$ & $\begin{array}{l}14.641 \text { *** } \\
(3.376)\end{array}$ & $\begin{array}{l}9.189^{*} \\
(5.154)\end{array}$ & $\begin{array}{l}8.042 \\
(4.775)\end{array}$ & $\begin{array}{l}8.667 \\
(7.302)\end{array}$ & $\begin{array}{l}6.710 \\
(7.060)\end{array}$ & $\begin{array}{l}10.819^{*} \\
(5.631)\end{array}$ & $\begin{array}{l}9.842 * \\
(5.382)\end{array}$ \\
\hline $\begin{array}{l}\text { Country Fixed } \\
\text { Effects? }\end{array}$ & Yes & Yes & No & No & Yes & Yes & No & No \\
\hline No. of Firms & 761 & 761 & 761 & 761 & 761 & 761 & 761 & 761 \\
\hline No. of Countries & 19 & 19 & 19 & 19 & 19 & 19 & 19 & 19 \\
\hline R-squared & 0.11 & 0.10 & 0.08 & 0.08 & 0.08 & 0.08 & 0.06 & 0.06 \\
\hline
\end{tabular}


Table 3A

Effect of Country-Level Measures of Corruption on Investment Growth: Pooled Sample (Transition Countries, Latin America and SSA)

\begin{tabular}{|c|c|c|c|c|c|c|c|c|}
\hline Variables & OLS & IRLS & OLS & IRLS & OLS & IRLS & OLS & IRLS \\
\hline \multicolumn{9}{|l|}{ Corruption } \\
\hline Bribe_Percent & $\begin{array}{l}-0.146 \\
(0.165)\end{array}$ & $\begin{array}{l}-0.180 * * \\
(0.079)\end{array}$ & & & & & & \\
\hline ICRG & & & $\begin{array}{l}-3.499 * * \\
(1.487) \\
\end{array}$ & $\begin{array}{l}-3.677 * * * \\
(0.611)\end{array}$ & & & & \\
\hline KKM & & & & & $\begin{array}{l}-5.226 \\
(3.393)\end{array}$ & $\begin{array}{l}-4.872 * * * \\
(1.542)\end{array}$ & & \\
\hline TI & & & & & & & $\begin{array}{l}-2.998 * * \\
(1.443)\end{array}$ & \begin{tabular}{|l}
$-2.784 * * *$ \\
$(0.739)$ \\
\end{tabular} \\
\hline \multicolumn{9}{|l|}{ Controls } \\
\hline Firm_Small & \begin{tabular}{|l|}
-3.195 \\
$(3.169)$
\end{tabular} & $\begin{array}{l}-1.948 \\
(2.912)\end{array}$ & $\begin{array}{l}-2.184 \\
(2.570)\end{array}$ & $\begin{array}{l}-0.398 \\
(2.242)\end{array}$ & $\begin{array}{l}-2.477 \\
(2.643)\end{array}$ & $\begin{array}{l}-0.548 \\
(2.249)\end{array}$ & $\begin{array}{l}-1.087 \\
(2.763)\end{array}$ & $\begin{array}{l}0.452 \\
(2.548)\end{array}$ \\
\hline Firm_Medium & $\begin{array}{l}-1.782 \\
(2.403)\end{array}$ & $\begin{array}{l}-1.722 \\
(2.544)\end{array}$ & $\begin{array}{l}-1.671 \\
(2.118)\end{array}$ & $\begin{array}{l}-0.544 \\
(2.018)\end{array}$ & $\begin{array}{l}-2.620 \\
(2.020)\end{array}$ & $\begin{array}{l}-1.476 \\
(2.019)\end{array}$ & $\begin{array}{l}-1.230 \\
(1.997)\end{array}$ & $\begin{array}{l}-0.290 \\
(2.281)\end{array}$ \\
\hline Service & $\begin{array}{l}9.692 * * * \\
(2.151) \\
\end{array}$ & $\begin{array}{l}9.418 * * * \\
(1.885) \\
\end{array}$ & $\begin{array}{l}8.786^{* * *} \\
(1.963) \\
\end{array}$ & $\begin{array}{l}8.113^{* * *} \\
(1.548) \\
\end{array}$ & $\begin{array}{l}8.244 * * * \\
(2.109) \\
\end{array}$ & $\begin{array}{l}7.651 * * * \\
(1.555) \\
\end{array}$ & $\begin{array}{l}9.197 * * * \\
(2.175) \\
\end{array}$ & $\begin{array}{l}8.458 * * * \\
(1.707) \\
\end{array}$ \\
\hline Exporter & $\begin{array}{l}8.362^{* * *} \\
(2.214) \\
\end{array}$ & $\begin{array}{l}8.397 * * * \\
(2.072)\end{array}$ & $\begin{array}{l}5.338^{* * *} \\
(1.943) \\
\end{array}$ & $\begin{array}{l}5.404 * * * \\
(1.645)\end{array}$ & $\begin{array}{l}5.289 * * * \\
(1.916)\end{array}$ & $\begin{array}{l}5.254 * * * \\
(1.657) \\
\end{array}$ & $\begin{array}{l}6.178 * * * \\
(2.040) \\
\end{array}$ & $\begin{array}{l}6.040 * * * \\
(1.832) \\
\end{array}$ \\
\hline Govt_Owned & $\begin{array}{l}-8.520^{* *} \\
(3.355) \\
\end{array}$ & $\begin{array}{l}-7.937 * * * \\
(2.834)\end{array}$ & $\begin{array}{l}-6.982 * * \\
(3.044) \\
\end{array}$ & $\begin{array}{l}-6.610^{* * * *} \\
(2.381)\end{array}$ & $\begin{array}{l}-7.749 * * \\
(3.022) \\
\end{array}$ & $\begin{array}{l}-7.536^{* * *} \\
(2.384)\end{array}$ & $\begin{array}{l}-7.399 * * \\
(3.217) \\
\end{array}$ & $\begin{array}{l}-7.474 * * * \\
(2.578)\end{array}$ \\
\hline Foreign_Owned & \begin{tabular}{|l|}
4.660 \\
$(2.904)$
\end{tabular} & $\begin{array}{l}5.176^{* * *} \\
(2.570)\end{array}$ & $\begin{array}{l}4.964 * * \\
(2.454)\end{array}$ & $\begin{array}{l}4.120 * * \\
(1.961)\end{array}$ & $\begin{array}{l}5.285^{* *} \\
(2.375)\end{array}$ & $\begin{array}{l}4.332 * * \\
(1.967)\end{array}$ & $\begin{array}{l}6.080^{* *} \\
(2.586)\end{array}$ & $\begin{array}{l}5.506^{* *} \\
(2.204)\end{array}$ \\
\hline GDP Growth & $\begin{array}{l}0.747 \\
(1.168) \\
\end{array}$ & $\begin{array}{l}0.919 * * \\
(0.414)\end{array}$ & $\begin{array}{l}0.690 \\
(0.801)\end{array}$ & $\begin{array}{l}0.820 * * \\
(0.346)\end{array}$ & $\begin{array}{l}0.541 \\
(1.034)\end{array}$ & $\begin{array}{l}0.681^{*} \\
(0.366)\end{array}$ & $\begin{array}{l}0.279 \\
(1.041)\end{array}$ & $\begin{array}{l}0.495 \\
(0.394)\end{array}$ \\
\hline $100 *$ Trade/GDP & \begin{tabular}{|l|}
0.044 \\
$(0.062)$
\end{tabular} & $\begin{array}{l}0.034 \\
(0.030)\end{array}$ & $\begin{array}{l}0.066 \\
(0.054)\end{array}$ & $\begin{array}{l}0.056^{* *} \\
(0.026)\end{array}$ & $\begin{array}{l}0.014 \\
(0.052)\end{array}$ & $\begin{array}{l}0.006 \\
(0.026)\end{array}$ & $\begin{array}{l}0.009 \\
(0.053)\end{array}$ & $\begin{array}{l}0.002 \\
(0.028)\end{array}$ \\
\hline Log (Inflation) & $\begin{array}{l}-1.473 \\
(1.815) \\
\end{array}$ & $\begin{array}{l}-1.726^{* *} \\
(0.854)\end{array}$ & $\begin{array}{l}-1.755 \\
(1.478) \\
\end{array}$ & $\begin{array}{l}-2.237 * * * \\
(0.721)\end{array}$ & $\begin{array}{l}-1.274 \\
(1.589)\end{array}$ & $\begin{array}{l}-1.769 * * \\
(0.736)\end{array}$ & $\begin{array}{l}-0.821 \\
(1.818)\end{array}$ & $\begin{array}{l}-1.392 \\
(0.853)\end{array}$ \\
\hline Constant & $\begin{array}{l}16.183^{* *} \\
(6.282) \\
\end{array}$ & $\begin{array}{l}16.582 * * * \\
(3.891)\end{array}$ & $\begin{array}{l}25.322 * * * \\
(7.062) \\
\end{array}$ & $\begin{array}{l}25.407 * * * \\
(3.467) \\
\end{array}$ & $\begin{array}{l}31.425^{* *} \\
(12.807) \\
\end{array}$ & $\begin{array}{l}30.009 * * * \\
(5.438)\end{array}$ & $\begin{array}{l}33.278^{* *} \\
(12.860) \\
\end{array}$ & $\begin{array}{l}31.906^{* * *} \\
(6.125)\end{array}$ \\
\hline No. of Firms & 2188 & 2188 & 2752 & 2752 & 2752 & 2752 & 2447 & 2447 \\
\hline No. of Countries & 37 & 37 & 53 & 53 & 53 & 53 & 46 & 46 \\
\hline
\end{tabular}


Table 4A

Effect of Country-Level Measures of Corruption on Investment Growth: Transition Countries

\begin{tabular}{|c|c|c|c|c|c|c|c|c|}
\hline Variables & OLS & IRLS & OLS & IRLS & OLS & IRLS & OLS & IRLS \\
\hline \multicolumn{9}{|l|}{ Corruption } \\
\hline Bribe_Percent & $\begin{array}{c}-0.918^{* *} \\
(0.408)\end{array}$ & $\begin{array}{c}-1.018^{* * *} \\
(0.174)\end{array}$ & & & & & & \\
\hline ICRG & & & $\begin{array}{c}-4.158^{* *} \\
(1.870)\end{array}$ & $\begin{array}{c}-4.468 * * * \\
(0.838)\end{array}$ & & & & \\
\hline KKM & & & & & $\begin{array}{c}-17.649 * * * \\
(5.404) \\
\end{array}$ & $\begin{array}{c}-18.664 * * * \\
(2.920) \\
\end{array}$ & & \\
\hline TI & & & & & & & $\begin{array}{c}-8.158^{* * *} \\
(2.166)\end{array}$ & $\begin{array}{c}-8.759 * * * \\
(1.352)\end{array}$ \\
\hline \multicolumn{9}{|l|}{ Controls } \\
\hline Firm_Small & $\begin{array}{l}10.317^{*} \\
(5.304)\end{array}$ & $\begin{array}{c}12.646^{* *} \\
(5.276)\end{array}$ & $\begin{array}{c}8.319 \\
(5.461)\end{array}$ & $\begin{array}{l}9.850^{*} \\
(5.293)\end{array}$ & $\begin{array}{c}8.161 \\
(5.840)\end{array}$ & $\begin{array}{l}9.429^{*} \\
(5.244)\end{array}$ & $\begin{array}{c}7.868 \\
(5.933)\end{array}$ & $\begin{array}{l}9.069 * \\
(5.249)\end{array}$ \\
\hline Firm_Medium & $\begin{array}{c}4.951 \\
(4.273)\end{array}$ & $\begin{array}{c}5.729 \\
(4.743)\end{array}$ & $\begin{array}{c}5.289 \\
(4.399)\end{array}$ & $\begin{array}{c}5.482 \\
(4.774)\end{array}$ & $\begin{array}{c}4.000 \\
(4.299)\end{array}$ & $\begin{array}{c}3.710 \\
(4.726)\end{array}$ & $\begin{array}{c}3.500 \\
(4.332)\end{array}$ & $\begin{array}{c}3.223 \\
(4.732)\end{array}$ \\
\hline Service & $\begin{array}{l}7.963 * * \\
(2.934)\end{array}$ & $\begin{array}{c}8.281 * * * \\
(2.703)\end{array}$ & $\begin{array}{l}7.431 * * \\
(2.885)\end{array}$ & $\begin{array}{c}7.415 * * * \\
(2.716)\end{array}$ & $\begin{array}{l}7.560^{* *} \\
(3.110)\end{array}$ & $\begin{array}{c}7.635 * * * \\
(2.691)\end{array}$ & $\begin{array}{l}7.503 * * \\
(3.052)\end{array}$ & $\begin{array}{c}7.466^{* * *} \\
(2.693)\end{array}$ \\
\hline Exporter & $\begin{array}{c}13.221 * * * \\
(3.137)\end{array}$ & $\begin{array}{c}13.770 * * * \\
(3.041)\end{array}$ & $\begin{array}{c}13.399 * * * \\
(3.178)\end{array}$ & $\begin{array}{c}13.856^{* * * *} \\
(3.058)\end{array}$ & $\begin{array}{c}11.961 * * * \\
(3.281)\end{array}$ & $\begin{array}{c}12.336^{* * * *} \\
(3.051)\end{array}$ & $\begin{array}{c}11.758^{* * *} \\
(3.343)\end{array}$ & $\begin{array}{c}11.958 * * * \\
(3.058)\end{array}$ \\
\hline Govt_Owned & $\begin{array}{l}-6.874 \\
(3.988)\end{array}$ & $\begin{array}{l}-6.514^{*} \\
(3.446)\end{array}$ & $\begin{array}{c}-6.384 \\
(4.192)\end{array}$ & $\begin{array}{c}-5.437 \\
(3.466)\end{array}$ & $\begin{array}{c}-6.452 \\
(4.450)\end{array}$ & $\begin{array}{l}-5.952^{*} \\
(3.435)\end{array}$ & $\begin{array}{l}-6.260 \\
(4.570)\end{array}$ & $\begin{array}{l}-5.716^{*} \\
(3.438)\end{array}$ \\
\hline Foreign_Owned & $\begin{array}{l}-0.706 \\
(5.018)\end{array}$ & $\begin{array}{c}-0.398 \\
(4.603)\end{array}$ & $\begin{array}{l}-0.836 \\
(5.556) \\
\end{array}$ & $\begin{array}{l}-1.170 \\
(4.631)\end{array}$ & $\begin{array}{c}-0.426 \\
(5.234) \\
\end{array}$ & $\begin{array}{l}-0.133 \\
(4.588)\end{array}$ & $\begin{array}{l}-1.054 \\
(5.265)\end{array}$ & $\begin{array}{c}-0.693 \\
(4.593) \\
\end{array}$ \\
\hline GDP Growth & $\begin{array}{c}-1.851 \\
(1.585) \\
\end{array}$ & $\begin{array}{c}-1.807 * * * \\
(0.670)\end{array}$ & $\begin{array}{c}0.089 \\
(1.081)\end{array}$ & $\begin{array}{c}0.414 \\
(0.523) \\
\end{array}$ & $\begin{array}{c}-0.468 \\
(1.121) \\
\end{array}$ & $\begin{array}{c}-0.170 \\
(0.534) \\
\end{array}$ & $\begin{array}{c}-0.632 \\
(1.103)\end{array}$ & $\begin{array}{c}-0.342 \\
(0.543) \\
\end{array}$ \\
\hline $100 *$ Trade/GDP & $\begin{array}{c}0.003 \\
(0.074) \\
\end{array}$ & $\begin{array}{c}-0.001 \\
(0.042) \\
\end{array}$ & $\begin{array}{c}0.043 \\
(0.083) \\
\end{array}$ & $\begin{array}{c}0.044 \\
(0.044) \\
\end{array}$ & $\begin{array}{c}-0.103^{*} \\
(0.058) \\
\end{array}$ & $\begin{array}{c}-0.119^{* * *} \\
(0.043)\end{array}$ & $\begin{array}{c}-0.151^{* *} \\
(0.059) \\
\end{array}$ & $\begin{array}{c}-0.170^{* * *} \\
(0.046) \\
\end{array}$ \\
\hline Log (Inflation) & $\begin{array}{c}-5.014 \\
(3.620)\end{array}$ & $\begin{array}{c}-5.289 * * * \\
(1.570)\end{array}$ & $\begin{array}{c}-2.580 \\
(3.024)\end{array}$ & $\begin{array}{c}-2.468 \\
(1.504)\end{array}$ & $\begin{array}{c}0.878 \\
(2.992)\end{array}$ & $\begin{array}{c}1.045 \\
(1.591)\end{array}$ & $\begin{array}{c}-0.895 \\
(3.132)\end{array}$ & $\begin{array}{c}-0.794 \\
(1.515)\end{array}$ \\
\hline Constant & $\begin{array}{l}54.412^{*} \\
(27.377)\end{array}$ & $\begin{array}{c}55.865^{* * *} \\
(11.819)\end{array}$ & $\begin{array}{c}23.672 \\
(17.046)\end{array}$ & $\begin{array}{c}20.909 * * \\
(9.208)\end{array}$ & $\begin{array}{c}59.556^{* * *} \\
(19.738)\end{array}$ & $\begin{array}{c}60.553^{* * *} \\
(11.716)\end{array}$ & $\begin{array}{c}75.045^{* * *} \\
(24.498)\end{array}$ & $\begin{array}{c}77.794 * * * \\
(13.544)\end{array}$ \\
\hline No. of Firms & 1278 & 1278 & 1278 & 1278 & 1278 & 1278 & 1278 & 1278 \\
\hline No. of Countries & 18 & 18 & 18 & 18 & 18 & 18 & 18 & 18 \\
\hline
\end{tabular}


Table 5A

Effect of Country-Level Measures of Corruption on Investment Growth: Latin American and Caribbean

\begin{tabular}{|c|c|c|c|c|c|c|c|c|}
\hline Variables & OLS & IRLS & OLS & IRLS & OLS & IRLS & OLS & IRLS \\
\hline \multicolumn{9}{|l|}{ Corruption } \\
\hline Bribe_Percent & $\begin{array}{c}0.150 \\
(0.096)\end{array}$ & $\begin{array}{c}0.146 \\
(0.103)\end{array}$ & & & & & & \\
\hline ICRG & & & $\begin{array}{c}-1.483 \\
(2.089) \\
\end{array}$ & $\begin{array}{c}-1.622 \\
(2.277)\end{array}$ & & & & \\
\hline KKM & & & & & $\begin{array}{l}4.160^{*} \\
(2.134) \\
\end{array}$ & $\begin{array}{l}4.473^{*} \\
(2.615) \\
\end{array}$ & & \\
\hline TI & & & & & & & $\begin{array}{l}2.346^{*} \\
(1.221)\end{array}$ & $\begin{array}{c}2.419 \\
(2.201) \\
\end{array}$ \\
\hline \multicolumn{9}{|l|}{ Controls } \\
\hline Firm_Small & $\begin{array}{c}-14.554^{* * *} \\
(3.621) \\
\end{array}$ & $\begin{array}{c}-12.878^{* * *} \\
(3.374) \\
\end{array}$ & $\begin{array}{c}-14.302^{* * *} \\
(3.545) \\
\end{array}$ & $\begin{array}{c}-13.042 * * * \\
(3.377) \\
\end{array}$ & $\begin{array}{c}-13.951 * * * * \\
(3.695)\end{array}$ & $\begin{array}{c}-12.450^{* * *} \\
(3.354)\end{array}$ & $\begin{array}{c}-14.542 * * * \\
(3.801)\end{array}$ & $\begin{array}{c}-13.597 * * * \\
(4.130)\end{array}$ \\
\hline Firm_Medium & $\begin{array}{c}-3.259 \\
(2.375)\end{array}$ & $\begin{array}{c}-2.233 \\
(2.849)\end{array}$ & $\begin{array}{l}-3.210 \\
(2.361)\end{array}$ & $\begin{array}{c}-2.202 \\
(2.850)\end{array}$ & $\begin{array}{c}-2.752 \\
(2.292)\end{array}$ & $\begin{array}{c}-1.862 \\
(2.856)\end{array}$ & $\begin{array}{c}-1.373 \\
(2.594)\end{array}$ & $\begin{array}{c}-0.368 \\
(3.465)\end{array}$ \\
\hline Service & $\begin{array}{c}11.139 * * * \\
(2.469) \\
\end{array}$ & $\begin{array}{c}8.628 * * * \\
(2.584) \\
\end{array}$ & $\begin{array}{c}11.169^{* * *} \\
(2.471) \\
\end{array}$ & $\begin{array}{c}8.601 * * * \\
(2.585) \\
\end{array}$ & $\begin{array}{c}11.217 * * * \\
(2.507) \\
\end{array}$ & $\begin{array}{c}8.697 * * * \\
(2.582) \\
\end{array}$ & $\begin{array}{c}12.410^{* * *} * \\
(2.886) \\
\end{array}$ & $\begin{array}{c}10.158^{* * *} \\
(3.071) \\
\end{array}$ \\
\hline Exporter & $\begin{array}{c}3.873 \\
(2.510) \\
\end{array}$ & $\begin{array}{c}3.958 \\
(2.723) \\
\end{array}$ & $\begin{array}{c}3.763 \\
(2.505) \\
\end{array}$ & $\begin{array}{c}3.669 \\
(2.722) \\
\end{array}$ & $\begin{array}{c}4.171 \\
(2.646) \\
\end{array}$ & $\begin{array}{c}4.186 \\
(2.734) \\
\end{array}$ & $\begin{array}{l}5.609^{* *} \\
(2.443)\end{array}$ & $\begin{array}{c}6.683 * * \\
(3.277) \\
\end{array}$ \\
\hline Govt_Owned & $\begin{array}{c}-8.948 \\
(5.699) \\
\end{array}$ & $\begin{array}{c}-7.278 \\
(6.975) \\
\end{array}$ & $\begin{array}{c}-9.162 \\
(5.416) \\
\end{array}$ & $\begin{array}{l}-7.728 \\
(6.982) \\
\end{array}$ & $\begin{array}{r}-8.139 \\
(5.804) \\
\end{array}$ & $\begin{array}{c}-6.556 \\
(6.987) \\
\end{array}$ & $\begin{array}{c}-7.337 \\
(6.881) \\
\end{array}$ & $\begin{array}{c}-7.231 \\
(9.031) \\
\end{array}$ \\
\hline Foreign_Owned & $\begin{array}{l}7.511^{*} \\
(3.908)\end{array}$ & $\begin{array}{c}7.357 * * * \\
(2.814)\end{array}$ & $\begin{array}{l}7.546^{*} \\
(3.921) \\
\end{array}$ & $\begin{array}{l}7.163^{* *} \\
(2.819)\end{array}$ & $\begin{array}{l}7.816^{*} \\
(3.868) \\
\end{array}$ & $\begin{array}{c}7.574 * * * \\
(2.810)\end{array}$ & $\begin{array}{c}10.287^{* *} \\
(4.083)\end{array}$ & $\begin{array}{c}10.027 * * * \\
(3.381)\end{array}$ \\
\hline GDP Growth & $\begin{array}{c}2.882 * * * \\
(0.679)\end{array}$ & $\begin{array}{l}1.911^{* *} \\
(0.852)\end{array}$ & $\begin{array}{l}2.186^{*} \\
(1.115) \\
\end{array}$ & $\begin{array}{c}1.164 \\
(1.043) \\
\end{array}$ & $\begin{array}{c}3.401 * * * \\
(0.379)\end{array}$ & $\begin{array}{c}2.568 * * * \\
(0.971)\end{array}$ & $\begin{array}{c}3.909 * * * \\
(1.167)\end{array}$ & $\begin{array}{c}3.449 \\
(2.235) \\
\end{array}$ \\
\hline $100 *$ Trade/GDP & $\begin{array}{l}0.101^{*} \\
(0.058) \\
\end{array}$ & $\begin{array}{c}0.114 * * \\
(0.051)\end{array}$ & $\begin{array}{c}0.091 \\
(0.064) \\
\end{array}$ & $\begin{array}{c}0.103^{* *} \\
(0.052) \\
\end{array}$ & $\begin{array}{c}0.074 \\
(0.062) \\
\end{array}$ & $\begin{array}{c}0.082 \\
(0.053)\end{array}$ & $\begin{array}{c}0.152^{* *} \\
(0.064)\end{array}$ & $\begin{array}{c}0.169^{* *} \\
(0.068)\end{array}$ \\
\hline Log (Inflation) & $\begin{array}{c}-0.762 \\
(0.859)\end{array}$ & $\begin{array}{l}-1.260 \\
(1.236)\end{array}$ & $\begin{array}{c}-1.375 \\
(1.183)\end{array}$ & $\begin{array}{l}-1.895 \\
(1.391)\end{array}$ & $\begin{array}{c}-0.842 \\
(0.987)\end{array}$ & $\begin{array}{c}-1.282 \\
(1.230)\end{array}$ & $\begin{array}{c}-1.895 \\
(1.154)\end{array}$ & $\begin{array}{c}-2.385 \\
(1.714) \\
\end{array}$ \\
\hline Constant & $\begin{array}{c}5.814 \\
(4.747) \\
\end{array}$ & $\begin{array}{c}7.161 \\
(5.483) \\
\end{array}$ & $\begin{array}{c}15.704 \\
(10.982) \\
\end{array}$ & $\begin{array}{c}17.864 \\
(10.856) \\
\end{array}$ & $\begin{array}{l}-2.612 \\
(6.954)\end{array}$ & $\begin{array}{l}-2.099 \\
(9.000)\end{array}$ & $\begin{array}{l}-9.616 \\
(8.762)\end{array}$ & $\begin{array}{l}-10.002 \\
(17.191)\end{array}$ \\
\hline No. of Firms & 910 & 910 & 910 & 910 & 910 & 910 & 718 & 718 \\
\hline No. of Countries & 19 & 19 & 19 & 19 & 19 & 19 & 15 & 15 \\
\hline
\end{tabular}


Table 6A

Effect of Country-Level Measures of Corruption on Investment Growth: Sub-Saharan Africa

\begin{tabular}{|c|c|c|c|c|c|c|}
\hline Variables & OLS & IRLS & OLS & IRLS & OLS & IRLS \\
\hline \multicolumn{7}{|l|}{ Corruption } \\
\hline ICRG & $\begin{array}{c}1.403 \\
(1.741)\end{array}$ & $\begin{array}{c}0.910 \\
(1.414)\end{array}$ & & & & \\
\hline KKM & & & $\begin{array}{c}-0.612 \\
(2.195)\end{array}$ & $\begin{array}{c}-0.567 \\
(2.222)\end{array}$ & & \\
\hline TI & & & & & $\begin{array}{l}-0.033 \\
(0.835)\end{array}$ & $\begin{array}{c}-0.197 \\
(0.846)\end{array}$ \\
\hline \multicolumn{7}{|l|}{ Controls } \\
\hline Firm_Small & $\begin{array}{c}4.260 \\
(4.501)\end{array}$ & $\begin{array}{c}6.576^{* *} \\
(2.791)\end{array}$ & $\begin{array}{c}4.605 \\
(4.598)\end{array}$ & $\begin{array}{c}6.844^{* *} \\
(2.789)\end{array}$ & $\begin{array}{c}.424 \\
(4.454)\end{array}$ & $\begin{array}{l}5.766^{*} \\
(3.005)\end{array}$ \\
\hline Firm_Medium & $\begin{array}{c}-1.375 \\
(4.973)\end{array}$ & $\begin{array}{l}4.386^{*} \\
(2.570)\end{array}$ & $\begin{array}{l}-1.002 \\
(5.095)\end{array}$ & $\begin{array}{l}4.694^{*} \\
(2.565)\end{array}$ & $\begin{array}{c}-0.534 \\
(3.761)\end{array}$ & $\begin{array}{c}6.755^{* *} \\
(2.818)\end{array}$ \\
\hline Service & $\begin{array}{c}8.966^{* *} \\
(3.601)\end{array}$ & $\begin{array}{c}7.109^{* * * *} \\
(2.301)\end{array}$ & $\begin{array}{c}9.039 * * \\
(3.675)\end{array}$ & $\begin{array}{c}7.180 * * * \\
(2.292)\end{array}$ & $\begin{array}{c}9.957^{* *} \\
(4.149)\end{array}$ & $\begin{array}{c}6.714 * * * \\
(2.469)\end{array}$ \\
\hline Exporter & $\begin{array}{l}-4.240 \\
(3.876)\end{array}$ & $\begin{array}{l}-1.848 \\
(2.088)\end{array}$ & $\begin{array}{l}-4.590 \\
(3.861)\end{array}$ & $\begin{array}{l}-2.128 \\
(2.060)\end{array}$ & $\begin{array}{l}-4.067 \\
(4.423)\end{array}$ & $\begin{array}{l}-3.384 \\
(2.331)\end{array}$ \\
\hline Govt_Owned & $\begin{array}{l}-1.162 \\
(4.766)\end{array}$ & $\begin{array}{l}-1.161 \\
(3.810)\end{array}$ & $\begin{array}{l}-0.919 \\
(5.004)\end{array}$ & $\begin{array}{l}-0.946 \\
(3.797)\end{array}$ & $\begin{array}{l}-2.695 \\
(5.431)\end{array}$ & $\begin{array}{l}-2.084 \\
(4.174)\end{array}$ \\
\hline Foreign_Owned & $\begin{array}{c}3.951 \\
(4.060)\end{array}$ & $\begin{array}{l}-1.779 \\
(2.264)\end{array}$ & $\begin{array}{c}3.940 \\
(4.035)\end{array}$ & $\begin{array}{l}-1.735 \\
(2.257)\end{array}$ & $\begin{array}{c}3.406 \\
(4.164)\end{array}$ & $\begin{array}{l}-2.507 \\
(2.443)\end{array}$ \\
\hline GDP Growth & $\begin{array}{c}1.387 \\
(1.484)\end{array}$ & $\begin{array}{l}-0.118 \\
(0.741)\end{array}$ & $\begin{array}{c}1.489 \\
(1.452)\end{array}$ & $\begin{array}{l}-0.073 \\
(0.744)\end{array}$ & $\begin{array}{c}1.585 \\
(1.237)\end{array}$ & $\begin{array}{l}-0.227 \\
(0.774)\end{array}$ \\
\hline 100*Trade/GDP & $\begin{array}{c}0.065 \\
(0.080)\end{array}$ & $\begin{array}{c}0.090 \\
(0.057)\end{array}$ & $\begin{array}{c}0.057 \\
(0.078)\end{array}$ & $\begin{array}{c}0.081 \\
(0.061)\end{array}$ & $\begin{array}{c}0.096 \\
(0.072)\end{array}$ & $\begin{array}{c}0.070 \\
(0.071)\end{array}$ \\
\hline Log (Inflation) & $\begin{array}{c}3.376 \\
(2.773)\end{array}$ & $\begin{array}{c}-0.887 \\
(1.425)\end{array}$ & $\begin{array}{c}3.554 \\
(2.568)\end{array}$ & $\begin{array}{l}-0.743 \\
(1.442)\end{array}$ & $\begin{array}{c}5.816^{* *} \\
(2.410)\end{array}$ & $\begin{array}{l}-0.458 \\
(1.597)\end{array}$ \\
\hline Constant & $\begin{array}{c}3.066 \\
(7.834)\end{array}$ & $\begin{array}{c}8.612 \\
(6.617)\end{array}$ & $\begin{array}{c}9.081 \\
(14.476)\end{array}$ & $\begin{array}{l}13.101 \\
(9.035)\end{array}$ & $\begin{array}{c}-2.410 \\
(12.756)\end{array}$ & $\begin{array}{l}13.532 \\
(9.554)\end{array}$ \\
\hline No. of Firms & 564 & 564 & 564 & 564 & 451 & 451 \\
\hline No. of Countries & 16 & 16 & 16 & 16 & 13 & 13 \\
\hline
\end{tabular}

